\title{
FLORA DA SERRA DO CIPÓ, MINAS GERAIS: MARCETIEAE (MELASTOMATACEAE)
}

\author{
MARIA JOSÉ REIS DA ROCHA*, DIEGO NUNES DA SILVA**, ROSANA ROMERO***, \\ PAULO JOSÉ FERNANDES GUIMARÃES**
}

\author{
*Universidade do Estado de Minas Gerais, Departamento de Ciências Biológicas, \\ Avenida São Paulo 3996, 32400-000, Ibirité, MG, Brasil. Autor para \\ correspondência: maria.rocha@uemg.br \\ **Instituto de Pesquisas Jardim Botânico do Rio de Janeiro, Rua Pacheco Leão 915, \\ 22460-030, Rio de Janeiro, RJ, Brasil. \\ ***Universidade Federal de Uberlândia, Instituto de Biologia, Rua Ceará s.n., \\ 38405-315, Uberlândia, Minas Gerais, Brasil.
}

\begin{abstract}
Flora of Serra do Cipó, Minas Gerais: Marcetieae (Melastomataceae)]. This study aims to increase knowledge about the family Melastomataceae in the Serra do Cipó, Minas Gerais and, consequently, to add new data to the project "Flora da Serra do Cipó, Minas Gerais". Marcetieae is a recently described tribe of Melastomataceae, represented in Brazil by 112 species and 18 genera, occurring predominantly in the savannas of the Amazon, cerrado and campo rupestre, rarely occurring in forest environments. At this date were registered at Serra do Cipó 15 species and six genera, Fritzschia is the richest genus with six species, followed by Marcetia and Siphanthera with three species each, and Aciotis, Acisanthera, Macairea are represented by only one species each. Identification keys to the genera and species, descriptions, field plates, and taxonomic notes including geographical distribution and habitat are presented.
\end{abstract}

Key words: cerrado, Espinhaço Range, endemism, Myrtales, rocky field, taxonomy.

Resumo - [Flora da Serra do Cipó, Minas Gerais: Marcetieae (Melastomataceae)]. Este estudo visa ampliar o conhecimento sobre a família Melastomataceae na Serra do Cipó, Minas Gerais e, consequentemente, agregar novos dados ao projeto "Flora da Serra do Cipó, Minas Gerais". Marcetieae é uma tribo recentemente descrita, representada no Brasil por 112 espécies e 18 gêneros, ocorrendo predominantemente na savana amazônica, cerrado, campo rupestre e, mais raramente, em ambientes florestais. Até o momento foram registradas na Serra do Cipó 15 espécies e seis gêneros, sendo Fritzschia o gênero mais representativo com seis espécies, seguido por Marcetia e Siphanthera com três espécies cada, e Aciotis, Acisanthera e Macairea com apenas uma espécie cada. São apresentadas chaves de identificação para os gêneros e espécies, descrições, pranchas de campo e notas taxonômicas, incluindo informações sobre distribuição geográfica e habitat.

Palavras-chave: Cadeia do Espinhaço, campo rupestre, cerrado, endemismo, Myrtales, taxonomia.

Tribo Marcetieae

M.J.R.Rocha, P.J.F.Guim. \& Michelang.

Ervas, arbustos ou subarbustos, raramente árvores, perenes ou anuais, eretas ou prostradas. Ramos cilíndricos a subcilíndricos, quadrangulares, raramente alados. Folhas decussadas, sésseis ou pecioladas, com indumento ou glabras. Flores 4-5meras, terminais ou axilares, isoladas ou em inflorescências; hipantos campanulados, elipsoides, (sub)globosos, oblongos, arredondados, (sub)urceolados, (sub)cilíndricos ou tubulosos; sépalas semicirculares, subuladas, triangulares, elípticas, lanceoladas, oblongas, lineares, obtusas; pétalas brancas, roxas, lilases, róseas, lilases com a base creme, ou raramente amarelas ou alaranjadas; estames dimórficos ou isomórficos, dialistêmones, 8-10 estames, raramente 4 , sendo os demais reduzidos a estaminódios ou ausentes por completo; filetes filiformes, glabros ou glandulosos na face ventral, anteras curvadas ou eretas, com ápice rostrado ou não, permanecendo truncado ou atenuado, pedoconectivos presentes ou ausentes, apêndices ventral e dorsal presentes ou ausentes; ovários 2-5-loculares, glabros ou com indumento, pluriovulados; estiletes filiformes, glabros ou com tricomas glandulosos da base até a metade; estigmas punctiformes ou truncados. Frutos cápsulas, raro bagas, polispérmicos; sementes cocleadas ou elipsoides a lacrimiformes, raro orbiculares ou subtriangulares, testas foveoladas, tuberculadas, raramente lisas.

Marcetieae é uma tribo proposta recentemente e exclusiva do Neotrópico. Compreende 19 gêneros e ca. de 140 espécies, comumente ervas ou pequenos arbustos, distribuídas desde o México e

Trabalho realizado segundo planejamento apresentado por Giulietti et al. (1987).

DOI: 10.11606/issn.2316-9052.v38ip15-31

Bol. Bot. Univ. São Paulo, São Paulo, v. 38, p. 15-31, 2020 
Antilhas até a Argentina, concentrando-se principalmente no cerrado e campo rupestre, nas savanas da região amazônica e nos planaltos das Guianas (Rocha et al. 2018). Embora apresentam uma considerável diversidade floral, a maioria dos seus representantes compartilham a presença de flores 4-meras, ovários 4loculares, ou menos comumente 2-3-loculares, glabros ou com tricomas glandulosos e sementes cocleadas
(Rocha et al. 2016, 2018), bem como a presença de três camadas no integumento do ovário como potencial sinapomorfia (Caetano et al. 2018).

Bibliografia básica: Martins (1989), Romero (1997), Freire-Fierro (2002), Almeda \& Robinson (2011), Michelangeli et al. (2013), Guimarães et al. (2017), Rocha et al. (2016, 2018), Silva (2018).

\section{Chave para identificação dos gêneros de Marcetieae da Serra do Cipó}

1. Flores 5-meras. 2 Acisanthera

1'. Flores 4-meras.

2. Filetes com tricomas glandulosos na face ventral 4 Macairea

2 '. Filetes glabros ou com tricomas glandulosos em ambas as faces.

3. Ovários 2-loculares.

4. Ovários semi-ínferos; sementes cocleadas, testas foveoladas

1 Aciotis

4'. Ovários súperos; sementes elipsoides a lacrimiformes, testas reticuladas 6 Siphanthera

3'. Ovários (3-)4-loculares.

5. Estames com pedoconectivos e apêndices ventrais

3 Fritzschia

5'. Estames sem pedoconectivos ou curtos e sem apêndices ventrais 5 Marcetia

1. Aciotis D.Don, Mem. Wern. Nat. Hist. Soc. 4: 300. 1823.

Ervas ou subarbustos, eretos. Ramos subquadrangulares, geralmente alados, glabros ou com tricomas. Folhas pecioladas, pubescentes, raramente glabras. Flores 4-meras, inflorescências cimosas ou paniculadas, terminais, brácteas semelhantes às folhas, mas menores; bractéolas diminutas; hipantos estriados; sépalas verdes, algumas vezes com ápice avermelhado, ou inteiramente avermelhadas; pétalas brancas a lilases, rósea-claro a vináceas; estames 8 , isomórficos, filetes glabros, pedoconectivos ausentes ou pouco desenvolvidos, apêndices ventrais e dorsais, quando presentes, inconspícuos, anteras orbiculares ou oblongas, eretas, ápice não rostrado, brancas a róseas ou púrpuras; ovários 2-loculares, ou mais raramente 3-loculares, semi-ínferos, glabros ou glanduloso-pubescentes; estiletes glabros; estigmas punctiformes. Frutos cápsulas, ou menos comumente bagas; sementes subcocleadas, testas foveoladas.

As espécies de Aciotis encontram-se distribuídas do sul do México ao norte da Bolívia, e no Brasil ocorre principalmente na região Norte. O Brasil configura como um dos principais centros de diversidade do gênero, representado por 13 espécies (Freire-Fierro 2002). Na Serra do Cipó ocorre Aciotis paludosa (Mart. ex DC.) Triana, que é preferencialmente encontrada em solos pedregosos e encharcados. Segundo Rocha et al. (2018), as espécies de Aciotis são reconhecidas pela presença de flores pequenas $(<1,5 \mathrm{~cm})$, quando comparado à maioria dos gêneros de Marcetieae, que possuem flores maiores que $1,5 \mathrm{~cm}$. Além das flores reduzidas, em Aciotis o pedoconectivo é ausente ou, quando presente, é pouco desenvolvido e não geniculado.
1.1. Aciotis paludosa (Mart. ex DC.) Triana, Trans. Linn. Soc. London 28(1): 51. 1871.

Fig. 1 A, B

Ervas, ca. 0,13-0,30 m alt. Ramos jovens quadrangulares, alados, tomentosos, tricomas eglandulosos avermelhados. Folhas pecioladas, pecíolos 5-10 mm compr.; lâminas 20-54 × 15-36 $\mathrm{mm}$, elípticas a ovais, base atenuada a cuneada ou obtusa, ápice obtuso, margem serrilhada ou serrilhado-ciliada, planas, membranáceas, 5 nervuras, face adaxial glabrescente, abaxial pubescente a glabrescente. Flores em inflorescências cimosas, bíparas, 24-36 $\mathrm{mm}$ compr., terminais, brácteas presentes, $1,2-1,5 \times$ ca. $0,5 \mathrm{~mm}$; pedicelos diminutos, ca. $1 \mathrm{~mm}$ compr.; hipantos ca. $3 \times 2-3 \mathrm{~mm}$, tubulosos ou globosos, estriados, esparsamente glandulosopubérulos; sépalas ca. 0,3 $\mathrm{mm}$ compr.; ovais, pétalas 2,5-5,5 × 1,5-2 mm, oblongas, lilases; estames subisomórficos, filetes ca. $1,8 \mathrm{~mm}$ compr., lilases, róseo claro ou vináceos; pedoconectivos ausentes ou até $0,1 \mathrm{~mm}$ compr., inapendiculados; anteras $0,8-1$ $\mathrm{mm}$ compr., oblongas, eretas, brancas; ovários 2loculares, ovoides, glabros; estiletes 3-3,5 mm compr., lilases. Bagas, 2-3 × 2-3 mm, verdes, pericarpo e placenta caducos quando maduros; sementes ca. 0,5 $\times 0,3 \mathrm{~mm}$, cocleadas, testas tuberculadas.

Aciotis paludosa ocorre no Brasil, preferencialmente no domínio Mata Atlântica, desde o estado do Paraná até Pernambuco, em altitudes entre 50 a 700 metros. Esta espécie foi registrada também no Mato Grosso, Maranhão e no Distrito Federal (Freire-Fierro 2002, Rosa \& Freire-Fierro 2020). Na Serra do Cipó foi coletada em beira de estrada, em solo pedregoso e encharcado, em altitude de $600 \mathrm{~m}$. Aciotis paludosa pode ser reconhecida pelo hábito herbáceo, folhas membranáceas e flores diminutas, 
Flora da Serra do Cipó, Minas Gerais: Marcetieae (Melastomataceae)
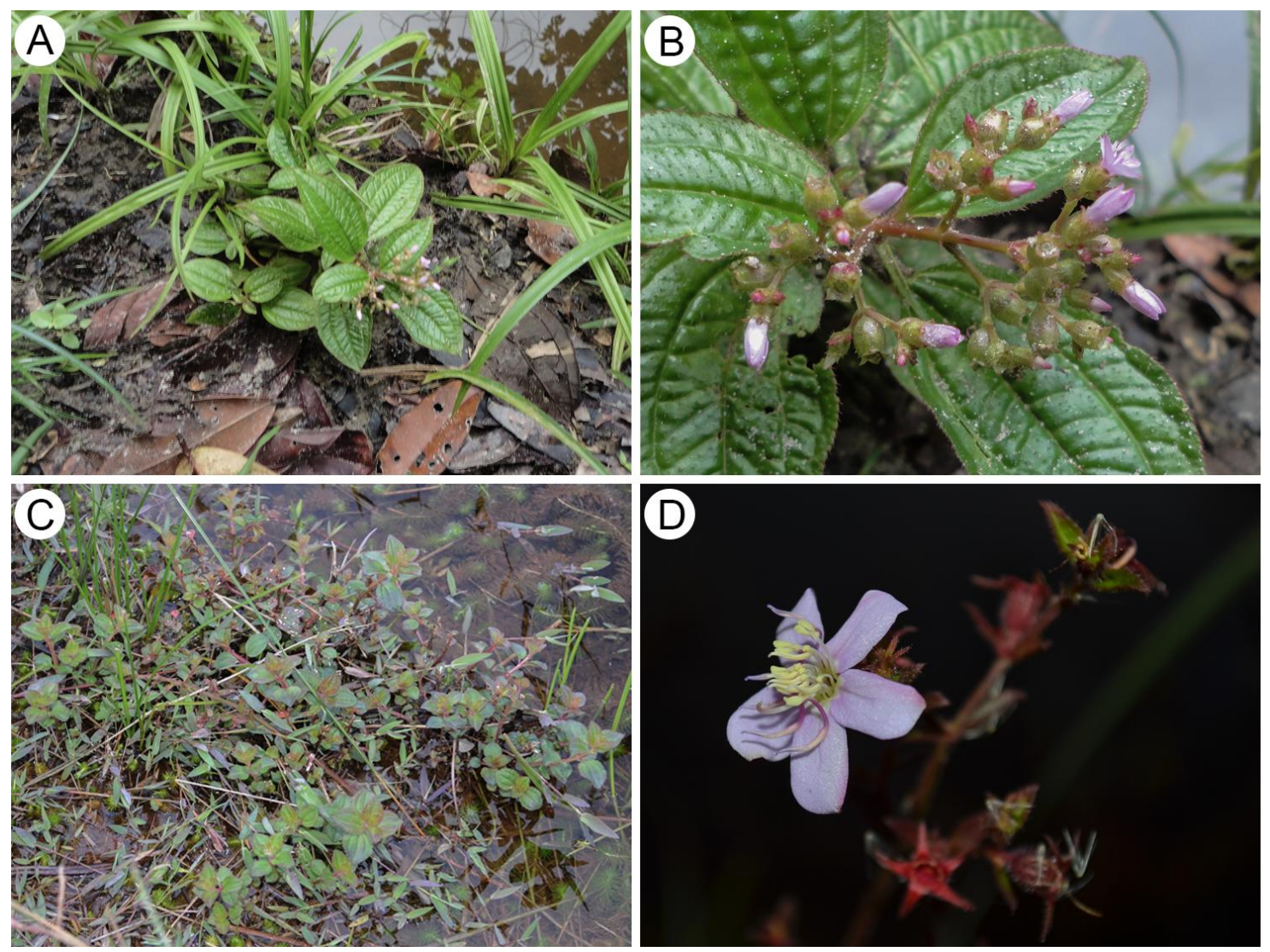

Fig. 1: Aciotis D.Don e Acisanthera P.Browne. A-B. Aciotis paludosa (Mart ex DC.) Triana. C-D. Acisanthera variabilis (DC.) Triana. [Fotos: A-D. M.J.R. Rocha].

dispostas em inflorescências cimosas bíparas, além da pilosidade avermelhada presente nos ramos e pecíolos.

Material examinado: Minas Gerais, Conceição do Mato Dentro, rio Santo Antônio, 18.I.1972, fl., fr., G.G. Hatschbach s.n. (MBM-21562-imagem online!). Morro do Pilar, a $2 \mathrm{~km}$ de Morro do Pilar, 31.VII.1979, fl., fr., G.J. Shepherd UEC 11206 (MO-2353926, UEC-004678-imagem online!).

\section{Acisanthera P.Browne, Civ. Nat. Hist. Jamaica 1: 217. 1756.}

Subarbustos, eretos. Ramos quadrangulares, hirsuto-glandulosos. Folhas pecioladas, pubescentes ou glabras. Flores 5-meras, inflorescências paniculadas, terminais; bractéolas presentes; hipantos campanulados, 10-estriados; sépalas esverdeadas; pétalas róseas; estames 10 , dimórficos, filetes glabros, pedoconectivos presentes, apêndices ventrais bilobados, curtos, anteras subuladas, curvadas, ápice atenuado, não rostrado, creme; ovários 3-loculares, glabros; estiletes glabros; estigmas punctiformes.
Frutos cápsulas; sementes subcocleadas, testas foveoladas.

O gênero Acisanthera foi recentemente recircunscrito por Rocha et al. (2018) e atualmente abriga cinco espécies, das quais três ocorrem no Brasil. As espécies são amplamente distribuídas na América Central e América do Sul, com exceção de poucos países. Na Serra do Cipó ocorre apenas Acisanthera variabilis (DC.) Triana.

2.1. Acisanthera variabilis (DC.) Triana, Trans. Linn. Soc. London 28: 34. 1871.

Fig. 1 C, D

Subarbustos, eretos, ca. $0,3 \mathrm{~m}$ alt. Ramos quadrangulares, hirsuto-glandulosos. Folhas pecioladas, pecíolos ca. $2 \mathrm{~mm}$ compr.; lâminas 7-12 × 4-11 mm, ovais a oval-oblongas, base arredondada, ápice agudo, margem serreada, ciliado-glandulosa, 5 nervuras, mais externas inconspícuas, face adaxial glabra ou com tricomas glandulosos esparsos, face abaxial hirsuto-glandulosa. Flores pediceladas; pedicelos ca. 1,5 mm compr.; hipantos ca. 2,5 × 2,5 
mm, campanulados, hirsuto-glandulosos; sépalas ca. 2 $\mathrm{mm}$ compr., subuladas, ápice glanduloso; pétalas 4-5 $\times$ 3,5-4 mm, oblongas, róseas, ápice arredondado, margem inteira, glabra; estames dimórficos, glabros, pedoconectivos creme, apêndices ventrais bilobados, creme, anteras subuladas, ápice atenuado, creme; estames antessépalos com filetes ca. $3 \mathrm{~mm}$ compr., pedoconectivos ca. 1,3 mm compr., apêndices ventrais 0,6-0,7 mm compr., anteras 2,8-3,3 mm compr., antepétalos com filetes 2,3-2,5 $\mathrm{mm}$ compr.; pedoconectivos ca. $0,2 \mathrm{~mm}$ compr., apêndices ventrais ca. $0,2 \mathrm{~mm}$ compr.; anteras 2,4-2,6 mm compr.; estiletes ca. $7 \mathrm{~mm}$ compr. Cápsulas, 3,3-4 × 2,7-3,2 $\mathrm{mm}$, globosas, castanhas; sementes $0,4-0,6 \times$ ca. 0,3 $\mathrm{mm}$, subcocleadas, testas foveoladas.

Material examinado: Minas Gerais, Jaboticatubas, Serra do Cipó, entre km 145 na estrada para Conceição do Mato Dentro, $19^{\circ} 10^{\prime} \mathrm{S}, 43^{\circ} 30^{\prime} \mathrm{W}, 2 . \mathrm{VI} .1998$, fl., fr., F. Almeda et al. 7784 (CAS, HUFU!, NY-3910203-imagem online!, UEC101662-imagem online!). Santana do Riacho, Serra do Cipó, 22.VII.1993, fl., J.A. Lombardi 391 (BHCB!); idem, Serra do Cipó, 24.VI.1993, fl., J.A. Lombardi 287 (BHCB!).

Material adicional examinado. Minas Gerais, Uberlândia, Reserva Ecológica do Clube Caça e Pesca Itororó de Uberlândia (CCPIU), 22.VIII.2012, fl., fr., A.F.A. Versiane et al. 242 (HUFU!).

Acisanthera variabilis ocorre nos estados de Santa Catarina, Paraná, São Paulo, Rio de Janeiro, Minas Gerais, Espírito Santo, Mato Grosso, Mato Grosso do Sul, Goiás, Piauí, Paraíba, Bahia, Amazonas e no Distrito Federal (Rocha et al. 2020), ocorrendo exclusivamente em locais úmidos. É facilmente reconhecida pelas folhas ovais a ovaloblongas com margem serreada e ciliado-glandulosa, indumento glanduloso recobrindo os ramos, folhas, hipantos e sépalas, e pétalas róseas, anteras creme e apêndice ventral do conectivo bilobado.

\section{Fritzschia Cham., Linnaea 9: 397. 1834.}

Ervas prostradas ou eretas; ou arbustos a subarbustos eretos. Ramos cilíndricos a quadrangulares, glabros, glandulosos, tricomas hirsuto-glandulosos ou glândulas esféricas esparsas. Folhas pecioladas, subsésseis ou sésseis, glabras ou com indumento. Flores 4-meras, solitárias, em dicásios ou panículas, axilares ou terminais; bractéolas semelhantes às folhas, raro com brácteas; hipantos 8-estriados; sépalas verde-claras, avermelhadas ou marrons; pétalas róseas, lilases ou roxas; estames 8, isomórficos, subisomórficos ou dimórficos; filetes glabros ou com indumento (apenas glândulas ou tricomas), pedoconectivos longos ou inconspícuos, eretos a curvados, glabros, apêndices ventrais bilobados ou auriculados, deltoides, oblongos ou ovais, glabros, apêndices dorsais bilobados, ovais, raros e inconspícuos, anteras oblongas, curvadas ou eretas, ápice atenuado ou não, não rostrado, amarelas, creme, lilases ou roxas; ovários 4-loculares, glabros ou com indumento no ápice; estiletes glabros ou com tricomas glandulosos da base até a metade; estigmas punctiformes. Cápsulas loculicidas, ovais; sementes cocleadas ou subcocleadas, testas foveoladas ou tuberculadas.

O gênero Fritzschia é endêmico do Brasil, sendo representado por 12 espécies, que ocorrem no Distrito Federal e estados da Bahia, Goiás, Mato Grosso do Sul e Minas Gerais, principalmente ao longo da Cadeia do Espinhaço, sendo encontradas em campo rupestre, mas também em campo limpo ou campo sujo (Silva 2018, Silva et al. 2019a, 2020). Na Serra do Cipó, as espécies do gênero são encontradas principalmente em ambientes abertos, próximas à cursos d'água ou mata de galeria, em solos hidromórficos ou arenosos, bem como em fendas de rochas, entre 724-1630 m de altitude.

Chave para as espécies de Fritzschia da Serra do Cipó [elaborada a partir de Silva et al. (2019b)]

1. Presença de um par de pequenas folhas nas axilas das folhas dos ramos principais; flores em dicásios reduzidos de duas flores (às vezes solitárias). 3.6 F. stenodon

1'. Ausência de um par de pequenas folhas nas axilas das folhas dos ramos principais; flores solitárias.

2. Lâminas foliares com margem fortemente revoluta.

3. Hipantos campanulados; pétalas com margem ciliado-glandulosa; estames antessépalos com lóbulos

3'. Hipantos oblongos; pétalas com margem glabra; estames antessépalos com lóbulos dos apêndices

2'. Lâminas foliares com margem plana ou levemente revoluta.

4. Lâminas foliares com margem serreada; anteras com ápice não atenuado; ápice do ovário glanduloso.... 3.4 F. rupestris

4'. Lâminas foliares com margem inteira ou serreada; anteras com ápice atenuado; ovários glabros.

5. Ramos com tricomas hirsuto-glandulosos; lâminas foliares com face abaxial avermelhada ou roxoescuro; hipantos oblongos; sépalas hirsuto-glandulosas e pétalas com a porção mediana-apical da margem direita revestidas por tricomas ciliado-glandulosos .............................................. 3.1 campanulados a urceolados; sépalas e pétalas glabras 
Flora da Serra do Cipó, Minas Gerais: Marcetieae (Melastomataceae)

3.1. Fritzschia atropurpurea D.Nunes, M.J.R.Rocha \& P.J.F.Guim., Syst. Bot. 44(4): 844. 2019.

Fig. 2 A

Ervas, prostradas. Ramos cilíndricos, hirsutoglandulosos, viscosos. Folhas pecioladas, pecíolos 0,5-1,2 mm compr.; lâminas 3-9 × 2-4 mm, lanceoladas ou ovais, base arredondada a levemente obtusa, raro atenuada, ápice obtuso ou arredondado, margem inteira, plana ou levemente revoluta; membranáceas, 3 nervuras (visíveis na face abaxial), nervura central calosa e secundárias tênues, faces abaxial e adaxial com tricomas hirsuto-glandulosos. Flores solitárias, terminais; somente bractéolas presentes; pedicelos 4-5,5 $\mathrm{mm}$ compr.; hipantos ca. $2,5 \times 2,1-2,5 \mathrm{~mm}$, oblongos, hirsuto-glandulosos; sépalas ca. $2 \times 0,9 \mathrm{~mm}$, linear-triangulares, verdes ou avermelhadas; pétalas ca. 9,5 ×5 mm, obovais, lilases ou róseas, margem direita com tricomas glandulosos na porção mediana-apical (vista pela face adaxial da pétala); estames dimórficos, glabros, filetes lilases, pedoconectivos eretos a levemente curvados, amarelos, apêndices ventrais bilobados, oblongos, amarelos, anteras oblongas, eretas, ápice atenuado, amarelas; estames antessépalos com filetes 3,3-3,5 $\mathrm{mm}$ compr., pedoconectivos 0,4-0,5 mm compr., apêndices ca. 0,3 mm compr., anteras 2-2,2 mm compr.; estames antepétalos com filetes ca. $3 \mathrm{~mm}$ compr., pedoconectivos 0,3-0,4 $\mathrm{mm}$ compr., apêndices ventrais ca. $0,2 \mathrm{~mm}$ compr., anteras ca. 2 $\mathrm{mm}$ compr.; ovários ca. $2 \times 2 \mathrm{~mm}$, ovais, glabros; estiletes ca. $8 \mathrm{~mm}$ compr., róseos ou roxos, glabros. Cápsulas, ca. $3 \times 2,8 \mathrm{~mm}$, marrons ou avermelhadas; sementes $0,6-0,7 \times 0,5-0,6 \mathrm{~mm}$, cocleadas, testas foveoladas.

Material examinado: Minas Gerais, Santana do Pirapama, Serra do Cipó, Fazenda Toucan Cipó, subida da captação de água, beira de riacho, 1900'21.42"S, 4345'20.27"W, 946 m, 18.XI.2009, fl., fr., D.C. Zappi et al. 2414 (RB!, K-000968556-imagem online!, SPF-00209677imagem online!); idem, Serra do Cipó (Serra da Lapa), Distrito de São José da Cachoeira, trilha da captação da Fazenda Toucan Cipó, $19^{\circ} 00^{\prime} 22 " \mathrm{~S}, 43^{\circ} 45^{\prime} 20 " \mathrm{~W}$, aprox. 680 $\mathrm{m}$ [970 m], 17.II.2007, fl., fr., V.C. Souza et al. 32582 (ESA097684-imagem online!, HUFU!, SPF-00183496-imagem online!). Santana do Riacho, RPPN Brumas do Espinhaço e Ermo dos Gerais, Ponto 96, [aprox. -19.03527848S, 43.71444375W], 1418 m, 19.IV.2012, fl., fr., J. Ordones et al. 1973 (BHZB!, HUFU!); idem, Brumas do Espinhaço, Ponto 109, [aprox. -19.02333212S, $-43.71833347 \mathrm{~W}$ ], $1235 \mathrm{~m}$, 29.XI.2012, fl., F.M. Fernandes et al. 337 (BHZB!, HUFU!).

Fritzschia atropurpurea é endêmica da Serra do Cipó, ocorrendo em campo rupestre em ambientes sombreados e úmidos, principalmente sob rochas e próximo a riachos, entre 946-1418 m de altitude (Silva et al. 2019b). Silva et al. (2019b) aproximaram F. atropurpurea ao congênere F. anisostemon Cham., mas distinguiram-na dessa pelos tricomas hirsutoglandulosos por toda a planta (vs. glabros em $F$. anisostemon), porção mediana-apical da margem direita das pétalas com tricomas glandulosos ( $v s$. glabras), lâminas foliares com face abaxial vinácea (vs. verde) e pedicelos com 4-5,5 $\mathrm{mm}$ de comprimento (vs. 2-3 mm).

3.2. Fritzschia cordifolia R.Romero, D.Nunes \& M.J.R.Rocha, Syst. Bot. 44(3): 664. 2019.

Fig. 2 B

Arbustos, eretos, ca. $0,3 \mathrm{~m}$ alt. Ramos cilíndricos, hirsuto-glandulosos, viscosos. Folhas sésseis ou pecioladas, pecíolos $0,4-0,6 \mathrm{~mm}$ compr.; lâminas $0,9-2 \times 0,7-2 \mathrm{~mm}$, cordiformes, base cordada, ápice arredondado ou levemente obtuso pela presença de uma única glândula esférica, margem inteira, fortemente revoluta, com glândulas esféricas, esparsas, suculentas, 1 nervura (visível na face abaxial), face abaxial hirsuto-glandulosa, face adaxial glabra. Flores solitárias e terminais; somente bractéolas presentes; pedicelos 0,9-2,1 $\mathrm{mm}$ compr.; hipantos 3-4 × ca. $2 \mathrm{~mm}$, campanulados, hirsutoglandulosos; sépalas 1-2 × 0,2-0,9 mm, lineartriangulares, avermelhadas; pétalas 7-11 × 5-6,2 mm, obovais, lilases ou róseas, toda margem com tricomas hirsuto-glandulosos; estames dimórficos, glabros, filetes creme ou róseos, pedoconectivos eretos a levemente curvados, creme, apêndices ventrais bilobados, creme ou amarelos, anteras oblongas, curvadas, ápice não atenuado, amarelas; estames antessépalos com filetes ca. $5 \mathrm{~mm}$ compr., pedoconectivos 2,3-2,8 $\mathrm{mm}$ compr., apêndices ventrais $0,6-1 \mathrm{~mm}$ compr., deltoides, anteras 2,5-4 $\mathrm{mm}$ compr.; estames antepétalos com filetes $4-4,5$ $\mathrm{mm}$ compr., pedoconectivos ca. $1 \mathrm{~mm}$ compr., apêndices ventrais $0,3-0,5 \mathrm{~mm}$ compr., oblongos, anteras 2-3 mm compr.; ovários ca. $2 \times 1-2 \mathrm{~mm}$, ovais, glabros; estiletes 7,3-12,5 compr., róseos ou roxos, glabros. Cápsulas, ca. $3 \times 2-3 \mathrm{~mm}$, marrons ou vináceas; sementes ca. $1,1 \times 0,5-0,8 \mathrm{~mm}$, subcocleadas, testas tuberculadas.

Material examinado: Minas Gerais, Congonhas do Norte, estrada para Santana do Riacho, Serra da Carapina, Setor N da Serra do Cipó, $18^{\circ} 55^{\prime} \mathrm{S}, 43^{\circ} 41^{\prime} \mathrm{W}, 1180-1260 \mathrm{~m}$, 3.III.1998, fr., J.R. Pirani et al. 4167 (SPF-00129657-imagem online!); Serra Talhada, $9 \mathrm{~km} \mathrm{~S}$ de Congonhas do Norte na estrada para Conceição do Mato Dentro, entrada para Extrema seguindo ca. $11 \mathrm{~km}$, estrada para Lapinha, $18^{\circ} 56^{\prime} 14.8^{\prime \prime S}, 43^{\circ} 41^{\prime} 6.1 " \mathrm{~W}, 1328 \mathrm{~m}$, 20.I.2007, fl., J.R. Pirani et al. 5607 (SPF, UEC!). Santana do Riacho, Lapinha, Serra do Cipó, estrada para Brumas do Espinhaço, $19^{\circ} 03^{\prime} 59^{\prime S}$, 4342'24"W, $1192 \mathrm{~m}$, 2.VII.2015, fl., fr., R. Romero et al. 8654 (HUFU!, RB!); idem, 1903'58"S, 4342'25"W, $1197 \mathrm{~m}$, 3.VII.2015, fl., fr., R. Romero et al. 8679 (BHCB!, HUFU!); idem, estrada Lapinha-Congonhas do Norte, entre fazenda Cachoeira e RPPN Ermo Gerais, $19^{\circ} 02^{\prime} 18^{\prime \prime}$, 4342'42"W, 1290 m, 19.I.2001, fl., A. Rapini et al. 1674 (HUEFS!, HTSA).

Fritzschia cordifolia é endêmica da Serra do Cipó, ocorrendo em campo rupestre, em ambientes abertos, principalmente sobre solos arenosos, entre 

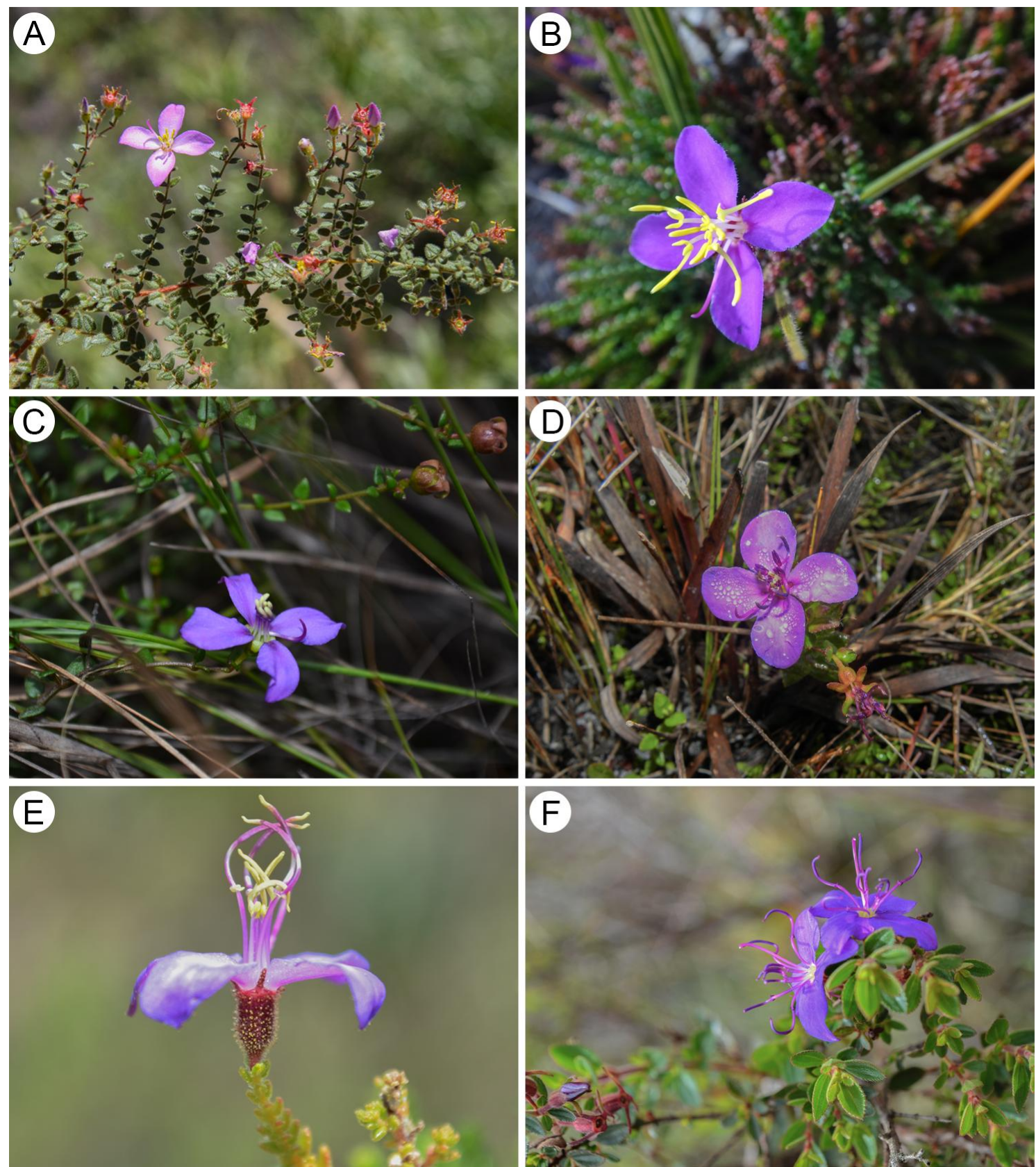

Fig. 2: Fritzschia Cham. A. F. atropurpurea D.Nunes, M.J.R.Rocha \& P.J.F.Guim. B. F. cordifolia R.Romero, D.Nunes \& M.J.R.Rocha. C. F. erecta Cham. D. F. rupestris R.Pacifico, Almeda \& D.Nunes. E. F. sertularia (Schrank \& Mart. ex DC.) M.J.R.Rocha \& P.J.F.Guim. F. F. stenodon (Naudin) M.J.R.Rocha \& P.J.F.Guim. [Fotos: A. D.C. Zappi; B. R. Romero; C-F. M.J.R. Rocha]. 
Flora da Serra do Cipó, Minas Gerais: Marcetieae (Melastomataceae)

1041-1328 m de altitude (Romero et al. 2019). Romero et al. (2019) aproximaram $F$. cordifolia à $F$. sertularia (Schrank \& Mart. ex DC.) M.J.R.Rocha \& P.J.F.Guim., mas distinguiram-na dessa pelas lâminas foliares cordadas ( $v s$. subcordadas a oblongas em $F$. sertularia), suculentas (vs. cartáceas) e com uma glândula no ápice (vs. sem glândula apical), hipantos campanulados ( $v s$. oblongos), margem das pétalas com tricomas glandulosos (vs. glabra), estames antessépalos com lóbulos do apêndice ventral deltoides (vs. lóbulos oblongos) e sementes com testa tuberculada (vs. testa foveolada). Fritzschia cordifolia é a única espécie do gênero que apresenta sementes com a testa tuberculada (Silva 2018, Romero et al. 2019). 1834

3.3. Fritzschia erecta Cham., Linnaea 9: 399.

Fig. 2 C

Ervas, prostradas ou eretas ou arbustos, decumbentes, 0,15-0,60 m alt. Ramos quadrangulares ou cilíndricos, glandulosos, viscosos. Folhas pecioladas, pecíolos $0,5-1(-2) \mathrm{mm}$ compr.; lâminas 2 $4(-6) \times(1,7-) 2-3 \mathrm{~mm}$, ovais, oval-oblongas ou oblanceoladas, base obtusa, arredondada a subcordada, ápice agudo, cuneado, raro obtuso, margem inteira ou serreada, plana ou levemente revoluta, cartáceas, 3 nervuras (visíveis na face abaxial), face abaxial glandulosa, face adaxial glabra ou glandulosa. Flores solitárias, terminais; somente bractéolas presentes; pedicelos 1-2(-4) mm compr.; hipantos 2-3 × 2-3 mm, campanulados ou urceolados, glabros ou com tricomas glandulosos; sépalas 2-3 $\times$ 1-1,3 mm, linear-triangulares, verdes ou marrons; pétalas (5-)6-10,5 × (3,5-)5-7 mm, obovais, lilases ou roxas, margem glabra; estames isomórficos, raramente subisomórficos, com filetes $2-3(-5) \mathrm{mm}$ compr., lilases ou roxos, glabros, pedoconectivos $0,1-$ 0,3 mm compr., eretos a levemente curvados, creme a amarelos, apêndices ventrais auriculados ou bilobados, 0,1-0,3 mm compr., ovais ou oblongos, lilases, roxos, ou creme a amarelos, anteras 1,7-2,5 $\mathrm{mm}$ compr., oblongas, eretas, ápice atenuado, creme à amarelas; ovários 1.5-2 × 1-2 mm, ovais, glabros; estiletes $5-8(-10) \mathrm{mm}$ compr., lilases ou roxos, glabros. Cápsulas, 2-3(-5) $\times 2-3(-5) \mathrm{mm}$, esverdeadas ou marrons; sementes $0,8-1,1 \times 0,7-0,8$ $\mathrm{mm}$, subcocleadas ou cocleadas, testas foveoladas.

Material examinado: Minas Gerais, Conceição do Mato Dentro, próximo ao km 170, [aprox. -19.090389, 43.453250], 800 m, 16.VII.1979, fl., G. Martinelli \& A. Távora 2599 (RB!). Jaboticatubas, km 115 ao longo da rodovia Lagoa Santa - Conceição do Mato Dentro - Diamantina, 15.XII.1971, fl., fr., J. Semir \& M. Sazima 607 (MBM, SP, UEC!, US-01900692-imagem online!). Morro do Pilar, Serra do Cipó, bifurcação de Conceição do Mato Dentro para Morro do Pilar, 19॰13'11"S, 4329'52"W, $1330 \mathrm{~m}$, II.2007, fl., fr., A.K.A. Santos et al. 1029 (BHCB!, HUEFS!). Santa Luzia, Serra do Cipó, km 127, [aprox. -19.765325, -43.852154], aprox. 748 m, 25.XI.1938, fl., H.L. Mello Barreto 8768
(BHCB!, UEC!). Santana do Riacho, entroncamento para Morro do Pilar, 14.II.2013, fl., M.J.R. Rocha \& R.P. Pena 895 (BHCB!, NY!)

Fritzschia erecta é endêmica da Cadeia do Espinhaço, Minas Gerais, ocorrendo em campo rupestre, em ambientes abertos, principalmente em solos arenosos ou próximo à cursos d'água (Silva 2018). Na Serra do Cipó, é encontrada entre 748$1400 \mathrm{~m}$ de altitude. Fritzschia erecta é morfologicamente similar à $F$. anisostemon Cham. e $F$. integrifolia Cham. (ver Chamisso 1834), essa última provavelmente um sinônimo. Entretanto, $F$. erecta e $F$. anisostemon podem ser diferenciadas pelo tamanho dos pedoconectivos dos estames antessépalos, que em $F$. erecta não ultrapassam $0,3 \mathrm{~mm}$ de comprimento (vs. ca. $2 \mathrm{~mm}$ compr. em $F$. anisostemon). Um morfotipo proveniente dos municípios de Jaboticatubas (A.M. Joly \& C. Müller 3435) e Morro do Pilar ( $F$. Almeda et al. 8612) tem gerado dúvidas quanto à sua verdadeira identidade (Silva 2018), por manter alguma semelhança com $F$. erecta, principalmente, com relação ao hábito, ramos viscosos, hipantos campanulados e estames (sub)isomórficos. Contudo difere pelas folhas e pétalas maiores e pela base subcordata das lâminas foliares (Silva 2018). No presente estudo, consideramos esse morfotipo como uma variação de $F$. erecta. Fritzschia erecta também apresenta alguma similaridade com $F$. rupestris R.Pacifico, Almeda \& D.Nunes e $F$. atropurpurea D.Nunes, M.J.R.Rocha \& P.J.F.Guim. [ver os comentários apresentados por Pacifico et al. (2018) e Silva et al. (2019b), respectivamente].

3.4. Fritzschia rupestris R.Pacifico, Almeda \& D.Nunes, Syst. Bot. 43: 794. 2018.

Fig. 2 D

Arbustos, decumbentes, 0,1-0,5 $\mathrm{m}$ alt. Ramos quadrangulares ou cilíndricos, glandulosos, viscosos. Folhas pecioladas, pecíolos $0,5-2 \mathrm{~mm}$ compr.; lâminas (5-)8-20 × (3-)5-16 mm, ovais ou subcordadas, base arredondada a subcordada, ápice agudo, margem serreada, plana ou levemente revoluta, cartácea, 3-5-nervuras (visíveis na face abaxial), nervuras calosas, par mais externo tênue, face abaxial glandulosa, face adaxial glandulosa ou glabra. Flores solitárias, terminais ou axilares; somente bractéolas presentes; pedicelos 2,5-4 mm compr.; hipantos 2-4 × 2-3 mm, campanulados, glandulosos ou glabros; sépalas $4-5 \times 1-1,8 \mathrm{~mm}$, oblongas, marrons ou avermelhadas; pétalas $8-8,5 \times$ 4,5-6 mm, obovais ou oval-lanceoladas, lilases ou roxas, margem esquerda com glândulas vermelhas na porção mediana-apical da face adaxial (vista pela face adaxial da pétala); estames dimórficos, glabros, filetes lilases ou roxos, pedoconectivos curvados, lilases ou roxos, apêndices ventrais bilobados, lilases ou roxos, anteras oblongas, curvadas, ápice não atenuado, lilases ou roxas; estames antessépalos com filetes 3-5 $\mathrm{mm}$ compr., pedoconectivos 2-4 $\mathrm{mm}$ compr., 
apêndices ventrais 1-1,5 $\mathrm{mm}$ compr., deltoides, anteras 3-4 mm compr.; estames antepétalos com filetes 2-4 $\mathrm{mm}$ compr., pedoconectivos 0,5-1 $\mathrm{mm}$ compr., apêndices ventrais 0,4-0,5 mm compr., oblongos, anteras 2,5-3,2 mm compr.; ovários 2-2,2 × ca. $2 \mathrm{~mm}$, ovais, glandulosos no ápice; estiletes 7,5$12,5 \mathrm{~mm}$ compr., lilases ou roxos, glabros. Cápsulas, 4-6 × 4-6 mm, marrons; sementes 0.7-1,2 × 0,6-0,8 $\mathrm{mm}$, subcocleadas, testas foveoladas.

Material examinado: Minas Gerais, Santana do Riacho, Serra do Cipó, km. 108, [aprox. -19.287222, 43.587778], aprox. 1220 m, 30.V.2001, fr., D. Negreiros s.n. (SPF-00150555-imagem online!); idem., km. 115, ca. $140 \mathrm{~N}$. of Belo Horizonte, [aprox. -19.2831, -43.5868], $1250 \mathrm{~m}$, 19.II.1968, fr., H.S. Irwin et al. 20466 (NY-01091948-imagem online!, UB, US-01901051-imagem online!); idem, "Santa Luzia", km 122, [aprox. -19.2889, -43.55224], $1195 \mathrm{~m}$, 14.IV.1942, fr., H.L. Mello Barreto \& Brade 1051 (BHCB!, RB!).

Fritzschia rupestris é endêmica da Cadeia do Espinhaço, Minas Gerais, ocorrendo em campo rupestre, em ambientes abertos, principalmente em fendas de rochas (Pacifico et al. 2018). Na Serra do Cipó, é encontrada entre 1195-1250 m de altitude (Pacifico et al. 2018). Pacifico et al. (2018) aproximaram $F$. rupestris à $F$. anisostemon Cham., mas distinguiram-na dessa, principalmente, pelas lâminas foliares ovais a subcordadas ( $v s$. ovais a elípticas em $F$. anisostemon), margens serreadas ( $v s$. irregulares) e ápice dos ovários com glândulas ( $v s$. glabro). Fritzschia rupestris é a única espécie do gênero com ovários glandulosos na região apical (Silva 2018).

3.5. Fritzschia sertularia (Schrank \& Mart. ex DC.) M.J.R.Rocha \& P.J.F.Guim., Int. J. Plant Sci. 179: 65. 2018.

Fig. 2 E

Arbustos ou subarbustos, eretos, 0,5-1 m alt. Ramos cilíndricos, hirsuto-glandulosos, viscosos. Folhas sésseis ou pecioladas, pecíolos $0,1-0,8 \mathrm{~mm}$ compr.; lâminas 1-3 × 0,8-2 mm, cordiformes à oblongas, base cordada, ápice arredondado ou agudo, margem inteira, fortemente revoluta, com glândulas esféricas, cartáceas, 1 nervura (visível na face abaxial), face abaxial revestida por tricomas hirsutoglandulosos, face adaxial glabra. Flores solitárias, terminais; somente bractéolas presentes; pedicelos 1,5-2 mm compr.; hipantos ca. $5 \times 2 \mathrm{~mm}$, oblongos, hirsuto-glandulosos; sépalas ca. 1,5 × 0,5-1 mm, linear-triangulares ou oblanceoladas, marrons ou avermelhadas; pétalas 6-11 × 4-6 mm, lanceoladas, oblanceoladas ou obovais, lilases ou roxas, margem glabra; estames dimórficos, glabros, filetes róseos ou roxos, pedoconectivos curvados, lilases, roxos ou com nuances de amarelo, apêndices ventrais bilobados, oblongos, lilases ou amarelos, anteras oblongas, curvadas, ápice não atenuado, amarelas, lilases ou roxas; estames antessépalos com filetes $5-6 \mathrm{~mm}$ compr., pedoconectivos 4-5 mm compr., apêndices ventrais $0,5-1 \mathrm{~mm}$ compr., anteras $6-7 \mathrm{~mm}$ compr.; estames antepétalos com filetes $4-5 \mathrm{~mm}$ compr., pedoconectivos ca. $1 \mathrm{~mm}$ compr., apêndices ventrais 0,3-0,7 mm compr., anteras 4,5-5 mm compr.; ovários ca. $3 \times 2 \mathrm{~mm}$, ovais ou oblongos, glabros; estiletes 12-15 mm compr., lilases ou roxos, glabros ou com tricomas glandulosos até a metade. Cápsulas, 4-6 $\times$ (3-)4-5 mm, marrons; sementes ca. 0,8 × 0,6-0,7 $\mathrm{mm}$, subcocleadas, testas foveoladas.

Material examinado: Minas Gerais, Congonhas do Norte, Serra Talhada, setor nordeste da Serra do Cipó, $9 \mathrm{~km}$ $S$ de Congonhas do Norte na estrada para conceição do Mato Dentro, entrada para Extrema seguindo ca. $11 \mathrm{~km}$ -

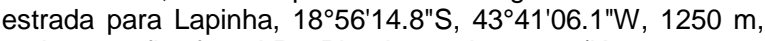
20.I.2007, fl., fr., J.R. Pirani et al. 5617 (K-000968150imagem online!, SPF!, UEC!). Morro do Pilar, Serra do Cipó, rodovia Cardeal Mota-Conceição do Mato Dentro, próximo ao trevo para Morro do Pilar, km 127, 19¹3'34"S, 4330'20"W, 1354 m, 1.VII.2015, fl., fr., R. Romero et al. 8624 (BHCB!, HUEM!, HUFU!). Santa Luzia, Serra do Cipó, km 139, [aprox. -19.624256, -43.771371], aprox. 820 m, 16.IV.1935, fr., H.L. Mello Barreto \& Brade 1164 (RB!). Santana do Pirapama, Serra do Cipó, acesso pela Faz. Inhame, trilha da Senhorinha, primeiro platô, $18^{\circ} 57^{\prime} 12^{\prime \prime S}, 43^{\circ} 46^{\prime} 21^{\prime \prime W}, 1128 \mathrm{~m}$, 10.III.2009, fr., D.C. Zappi et al. 2027 (RB!, SPF-00209611imagem online!). Santana do Riacho, Serra do Cipó, próximo à estátua do Juquinha, 19¹5'30"S, 433'04"W, $1500 \mathrm{~m}$, 5.VII.2001, fr., V.C. Souza et al. 25212 (BHCB!, ESA-073463imagem online!, MBM!, SPF!, UEC!).

Fritzschia sertularia ocorre principalmente na Cadeia do Espinhaço, Minas Gerais, sendo encontrada na Serra do Cabral, Serra do Caraça e Serra do Cipó, em campo rupestre e campo úmido, próximos a cursos d'água, ocorrendo entre rochas ou em solos arenosos ou pedregosos (Silva 2018). Na Serra do Cipó, essa espécie é encontrada entre 800$1500 \mathrm{~m}$ de altitude. Fritzschia sertularia aproxima-se de $F$. cordifolia, que também ocorre na Serra do Cipó, e ambas têm sido diferenciadas por características mencionadas nos comentários de F. cordifolia.

3.6. Fritzschia stenodon (Naudin) M.J.R.Rocha \& P.J.F.Guim., Int. J. Plant Sci. 179: 65. 2018.

Fig. $2 \mathrm{~F}$

Subarbustos, eretos, 0,4-1,5(-2) m alt. Ramos quadrangulares ou cilíndricos, hirsutoglandulosos, viscosos. Folhas pecioladas, pecíolos 1$4 \mathrm{~mm}$ compr.; lâminas 5-10(-20) × 3-8(-15) mm, ovais à oval-lanceoladas, base atenuada ou oval, ápice agudo, margem serreada, ciliado-glandulosa, plana ou levemente revoluta, membranáceas, (3-)5nervuras, nervura central e primeiro par de nervuras secundárias calosas, segundo par de nervuras secundárias tênues; presença de um par de folhas pecioladas na base de cada pecíolo das folhas principais, lâmina 3-5 × 1,2-3 mm, ambas as faces hirsuto-glandulosas. Flores solitárias ou em dicásio reduzido à duas flores, indeterminado, axilares; brácteas e bractéolas presentes, oblongas; pedicelos 
2-5 mm compr.; hipantos 3,5-6 $\times 2-3 \mathrm{~mm}$, oblongos, hirsuto-glandulosos; sépalas 4-7(-8) × 0,7-1(-1,3) $\mathrm{mm}$, oblongas à oblanceoladas, beges ou marrons; pétalas 7-10 × 4-7 mm, obovais, lilases ou roxas, margem glabra; estames dimórficos, glabros, filetes lilases ou roxos, pedoconectivos curvados, brancos, lilases ou roxos, apêndices ventrais bilobados, oblongos, brancos ou roxos, anteras oblongas, curvadas, ápice não atenuado, amarelas, lilases ou roxas; estames antessépalos com filetes 6-8 $\mathrm{mm}$ compr., pedoconectivos (2,5-)3-4 mm compr., apêndices ventrais $0,2-0,5 \mathrm{~mm}$ compr., anteras 5-7(8) $\mathrm{mm}$ compr.; estames antepétalos com filetes 4-6 $\mathrm{mm}$ compr., pedoconectivos 1-3 $\mathrm{mm}$ compr., apêndices ventrais $0,2-0,3(-0,5) \mathrm{mm}$ compr., anteras 4,5-6(-7) mm compr.; ovários (2,5-)3-4 × 2-3 mm, ovais, glabros; estiletes 10-16(-19) mm compr., lilases ou roxos, glabros. Cápsulas, (3-)5-6(-7) × (2-)3-4 $\mathrm{mm}$, marrons; sementes 0,5-0,6 $\times$ 0,3-0,4 mm, cocleadas, testas foveoladas.

Material examinado: Minas Gerais, Conceição do Mato Dentro, "Jaboticatubas", Serra do Cipó, entre 119-120 $\mathrm{km}$ na entrada para Conceição do Mato Dentro, 19¹0'S, 4330'W, aprox. $1230 \mathrm{~m}$, 1.VI.1998, fl., fr., F. Almeda et al. 7772 (CAS, HUFU!, RB!, UEC!). Jaboticatubas, km 115 ao longo da rodovia Lagoa Santa - Conceição do Mato Dentro Diamantina, [aprox. -19.519157, -43.883231], aprox. $747 \mathrm{~m}$, 29.IV.1973, fl., J. Semir et al. CFSC 4081 (SP!). Morro do Pilar, Parque Nacional da Serra do Cipó, entroncamento da MG-010 em direção ao Morro do Pilar, 19¹3'10"S, 4329'43"W, aprox. 1305 m, 18.VI.2012, fl., M.J.R. Rocha \& R.C. Ribeiro 696 (BHCB!, NY!, RB!). Santa Luzia, Serra do Cipó, km 134, 25.X.1961, fl., fr., A.P. Duarte 6403 (RB!, US01891414-imagem online!). Santana do Pirapama, Fazenda Inhame (Serra Mineira), Serra do Cipó, $18^{\circ} 55^{\prime} \mathrm{S}, 43^{\circ} 54^{\prime} \mathrm{W}$, aprox. 724 m, J.R. Pirani et al. 8162 (SP!, UEC!). Santana do Riacho, Brumas do Espinhaço e Ermo do Gerais, ponto 103, 1355 m, 29.I.2013, fl., fr., F.M. Fernandes et al. 386 (BHZB!, HUFU!).

Fritzschia stenodon é endêmica da Cadeia do Espinhaço, Minas Gerais, ocorrendo em campo rupestre, principalmente, próximo a cursos d'água ou mata de galeria, em solos hidromórficos ou arenosos, bem como em fendas de rochas (Silva 2018). Na Serra do Cipó é encontrada entre 724-1355 m de altitude. Fritzschia stenodon é prontamente diferenciada dos demais congêneres pela combinação de características vegetativas: folhas ovais a ovallanceoladas com margem serreada, ciliado-glandulosa e presença de um par de pequenas folhas na base de cada pecíolo das folhas dos ramos principais (Seco 2006).

\section{Macairea DC., Prodr. 3: 109. 1828.}

Arbustos, eretos. Ramos cilíndricos, setoso glandulosos, frequentemente com galhas. Folhas pecioladas, pubescentes ou glabras. Flores 4-meras, inflorescências tirsos multifloros, terminais; bractéolas presentes; hipantos oblongos ou campanulados, estriados; sépalas esverdeadas; pétalas lilases com base creme; estames 8, dimórficos; filetes glandulosos na face ventral, raro glabros, pedoconectivos presentes, apêndices ventrais projetados dorsobasalmente na inserção do filete, anteras subuladas, curvadas, ápice atenuado, não rostrado, amarelas; ovários (2-3-)4-loculares, ápice glanduloso ou seríceo; estiletes na metade inferior com tricomas glandulosos esparsos; estigmas punctiformes. Frutos cápsulas; sementes cocleadas, testas tuberculadas.

O gênero Macairea apresenta 22 espécies distribuídas nas Guianas, Venezuela, Colômbia, Bolívia e Brasil (Renner 1989), onde ocorrem 11 espécies (Silva-Gonçalves 2020). As flores 4-meras com oito estames dimórficos, pedoconectivos projetados dorso-basalmente na inserção do filete, ovários frequentemente 4-loculares com ápice piloso e a presença frequente de galhas nos ramos principais são características diagnósticas que permitem reconhecê-lo prontamente (Renner 1989).

\subsection{Macairea radula (Bonpl.) DC., Prodr. 3: 109.} 1828.

Fig. 3 A, B

Arbustos, eretos, ca. $1,5 \mathrm{~m}$ alt. Ramos cilíndricos, seríceo-glandulosos. Folhas pecioladas, pecíolos 15-20 mm compr.; lâminas $50-60 \times 12-25$ $\mathrm{mm}$, elípticas, base atenuada, ápice obtuso a arredondado, margem inteira, ciliada, cartáceas, 5 nervuras, par mais interno suprabasal, mais externo basal e inconspícuo, face abaxial densamente vilosoglandulosa, face adaxial seríceo-estrigosa, bulada. Tirsos multifloros, 80-180 mm compr., bractéolas 7-8 $\times$ 1-1,5 mm, lineares; pedicelos 4-5 mm compr; hipantos 2,5-3 $\times$ 2,5-3 $\mathrm{mm}$, oblongos a campanulados, 10-estriados, seríceo-glandulosos; sépalas 2,5-3 × 0,5-2 mm, triangulares, seríceoglandulosas; pétalas 8-11 ×4-6 mm, obovais, róseas ou lilases com base creme; estames dimórficos, estames antessépalos com filetes 5-9 mm compr., amarelos, purpúreos na base, com tricomas glandulosos na face ventral, pedoconectivos 1,5-3,5 $\mathrm{mm}$ compr., expandidos dorso-basalmente; anteras 3,5-4,5 mm compr.; estames antepétalos com filetes 3.5-6 mm compr., amarelos, com tricomas glandulosos na face ventral, pedoconectivos 1,5-2 mm compr., expandidos dorso-basalmente; anteras 3-3,5 $\mathrm{mm}$ compr.; ovários 4-loculares, globosos, ápice esparsamente glanduloso; estiletes 4-10 mm compr., purpúreos. Cápsulas, 3-4 × 2-3 mm, globosas, atropurpúreas; sementes ca. 0,5 × 0,4 mm.

Material examinado selecionado: Minas Gerais, Alto do Palácio, 3.VI.1986, fl., M. Brandão 11699 (HUFU!). Conceição do Mato Dentro, Serra do Cipó, Rodovia BHConceição do Mato Dentro, 1902'14"S, 4325'30W", 4.X.1990, fl., F.R.G. Salimena \& R.F. Novelino 326 (CESJ). Jaboticatubas, Parque Nacional da Serra do Cipó, trilha do 

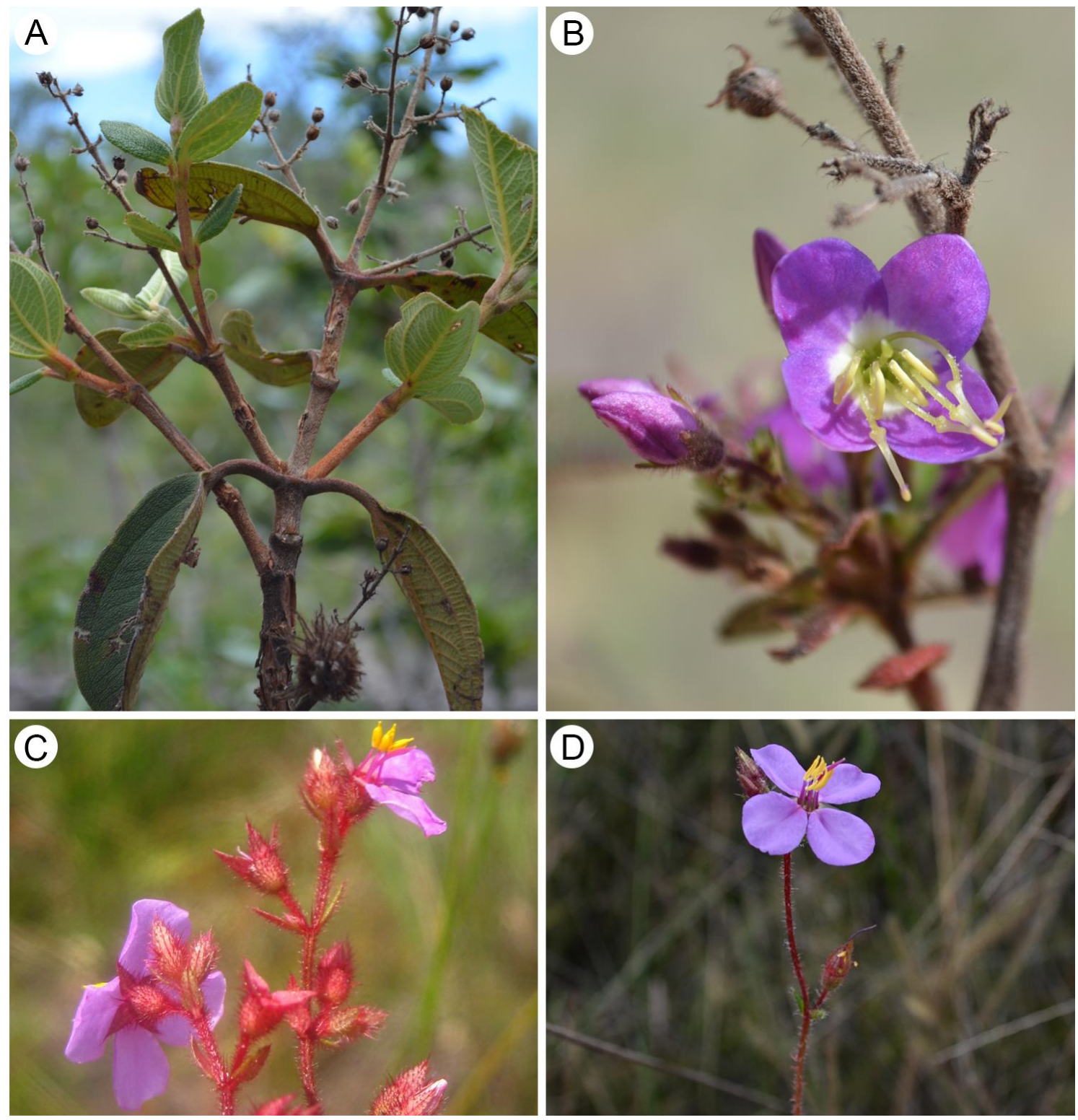

Fig. 3: Macairea DC. e Siphanthera Pohl ex DC. A-B. Macairea radula (Bonpl.) DC. A. Detalhe de um ramo, mostrando indumento, folhas e frutos. B. Flor, evidenciando a corola bicolor e os filetes glandulosos. C. $S$. arenaria (DC.) Cogn., ramos e folhas avermelhados. D. S. paludosa (DC.) Cogn., ramo avermelhado mostrando $\mathrm{o}$ indumento e a flor em detalhes. [Fotos: A-D. M.J.R. Rocha]. 
Flora da Serra do Cipó, Minas Gerais: Marcetieae (Melastomataceae)

Capão, 1920'57"S, 43ำ37'01"W, 12.VIII.2012, fl., S.S. Oliveira 113 (BHCB!); idem, Parque Nacional da Serra do Cipó, Cachoeira da Farofa, portaria do Retiro, após bifurcação para a Cachoeira da Farofa até o Riacho, 1920'56"S, 4334'38"W, 16.X.2013, fl., M. Verdi et al. 6739 (HUFU!); idem, Serra do Cipó, km 117 ao longo da rodovia Lagoa Santa-Conceição do Mato DentroDiamantina, 19³0'49"S, 4344'42"W, 4.IX.1973, fl., J. Semir et al. 4403 (SP!). Santana do Pirapama, Serra do Cipó, Fazenda Toucan Cipó, perto da sede, 18 59'17"S, 43ํㄴ'57"W, 20.XI.2009, fl., D.C. Zappi 2450 (SPF!). Santana do Riacho, Serra do Cipó, 21.IX.1997, fl., Y.L. Nunes et al. s.n. (HUFU!); idem, distrito de Cardeal Mota, Cadeia do Espinhaço, Serra do Cipó, arredores da Cachoeira Véu da Noiva, trilha dos Escravos, 19³1'54"S, $44^{\circ} 00^{\prime} 09^{\prime W}$, 15.XI.2013, fl., F.S. Meyer \& N.A.G. Escobar 1757 (UEC-114987-imagem online!); idem, Serra do Cipó, Distrito de Cardeal Mota, sede da fazenda Monjolos, cerrado em torno da sede, $19^{\circ} 10^{\prime} 08^{\prime \prime S}, 43^{\circ} 42^{\prime} 52^{\prime \prime W}$, 24.IX.2002, fl., L.S. Kinoshita 02/131 (UEC-044360imagem online!); idem, Serra do Cipó, IX.1989, fl., $M$. Sobral 6251 (UPCB-0014904-imagem online!).

Macairea radula é encontrada na Bolívia e no Brasil (Renner 1989), onde apresenta ampla distribuição, ocorrendo nos estados de São Paulo, Espírito Santo, Rio de Janeiro, Minas Gerais, Goiás, Mato Grosso do Sul, Mato Grosso, Bahia, Piauí, Maranhão, Amazonas, Pará, Rondônia, Tocantins e no Distrito Federal (Silva-Gonçalves 2020). Na Serra do Cipó é encontrada em borda de mata de galeria, em campo rupestre próximo a cursos d'água e, ocasionalmente, em cerrado. Macairea radula é reconhecida por suas flores 4-meras com pétalas róseas ou lilases e base creme, que adquire coloração avermelhada após a polinização. Ademais, apresenta filetes com tricomas glandulosos somente na face ventral.

\section{Marcetia DC., Prodr. 3: 124. 1828.}

Ervas, subarbustos ou arbustos, decumbentes, eretos ou prostrados. Ramos cilíndricos a subcilíndricos, decorticantes na base, tricomas glandulosos ou eglandulosos. Folhas sésseis ou pecioladas, pubescentes ou glabras. Flores 4-meras, em dicásios ou comumente flores solitárias, terminais ou axilares; brácteas e bractéolas presentes ou ausentes, em geral semelhantes às folhas em tamanho e/ou formato; hipantos 8-estriados; sépalas esverdeadas, marrons ou vináceas, com ou sem dentículos entre as sépalas; pétalas brancas, lilases, róseas, púrpuras, raramente alaranjadas; estames 8 , isomórficos, raramente subisomórficos; filetes glabros, pedoconectivos curtos, levemente espessos na base das tecas, inapendiculados ou raro com apêndices, anteras lineares ou oblongas, eretas, ou raramente curvadas, ápice atenuado, não rostrado, amarelas a alaranjadas; ovários 3-4-loculares, glabros; estiletes glabros; estigmas punctiformes. Frutos cápsulas, em geral igual ou excedendo o hipanto, globosas; sementes cocleadas ou subcocleadas, testas foveoladas ou tuberculadas.

O gênero Marcetia está representado por 30 espécies (Santos 2020). Com exceção de Marcetia taxifolia (A.St.-Hil.) DC., que possui ampla distribuição, o gênero é endêmico no Brasil, sendo a Bahia o principal centro de diversidade (Martins 2000, Santos 2008). Em Minas Gerais são registradas sete espécies, destas três ocorrem na Serra do Cipó, M. acerosa Schrank \& Mart. ex DC., M. semiriana A.B. Martins e $M$. taxifolia. $O$ gênero Marcetia é tipicamente reconhecido dentro de Marcetieae pelas anteras eretas, pedoconectivos curtos, espessados na base das tecas e pela ausência de apêndices do conectivo (Rocha et al. 2018).

\section{Chave para as espécies de Marcetia da Serra do Cipó}

1. Cápsula excedendo o hipanto 5.1 M. acerosa

1 . Cápsula igual ou menor que o hipanto.

2. Estames isomórficos; anteras eretas, oblongas. 5.2 M. semiriana

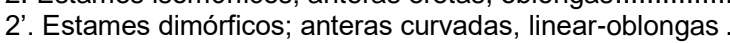
5.3 M. taxifolia

5.1. Marcetia acerosa Schrank \& Mart. ex DC. Prod. 3: 125.128

Fig. $4 \mathrm{~A}$

Ervas ou subarbustos, decumbentes, 0,1-0,2 $\mathrm{m}$ alt. Ramos subcilíndricos, comumente muito ramificados, decorticantes e avermelhados na base, revestidos por tricomas híspidos. Folhas subsésseis, pecíolos ca. 0,2 mm compr.; lâminas 1-2,5 × 0,5-1 $\mathrm{mm}$, oval-lanceoladas, base truncada ou arredondada, ápice agudo, margem inteira, revoluta, cartáceas, 3 nervuras, par externo delgado e pouco conspícuo, ambas as faces densamente pubescentes. Flores solitárias, terminais, bractéolas ausentes; pedicelos 0,5-1,3 $\mathrm{mm}$ compr.; hipantos 0,8-2 × 1-2 mm, campanulados, esparsamente híspidos; sépalas 1-3 x ca. $1 \mathrm{~mm}$, triangulares, com dentículos entre as sépalas; pétalas 4,5-6 × 4-5 mm, obovais, lilases ou roxas; estames subisomórficos, filetes 2-4 mm compr., brancos a avermelhados, pedoconectivos 0,2-0,3 $\mathrm{mm}$ compr., espessos, inapendiculados; anteras 1,5-2 $\mathrm{mm}$ compr., oblongas, eretas, amarelas passando a alaranjadas; ovários 3-4-loculares, oval-elípticos; estiletes 4-7 $\mathrm{mm}$ compr., brancos a avermelhados. Cápsulas, 2,3-3,4 × 3-3,6 mm, vináceas ou castanhas, excedendo o hipanto; sementes $0,5-1 \times$ ca. $0,8 \mathrm{~mm}$, subcocleadas, testas foveoladas. 

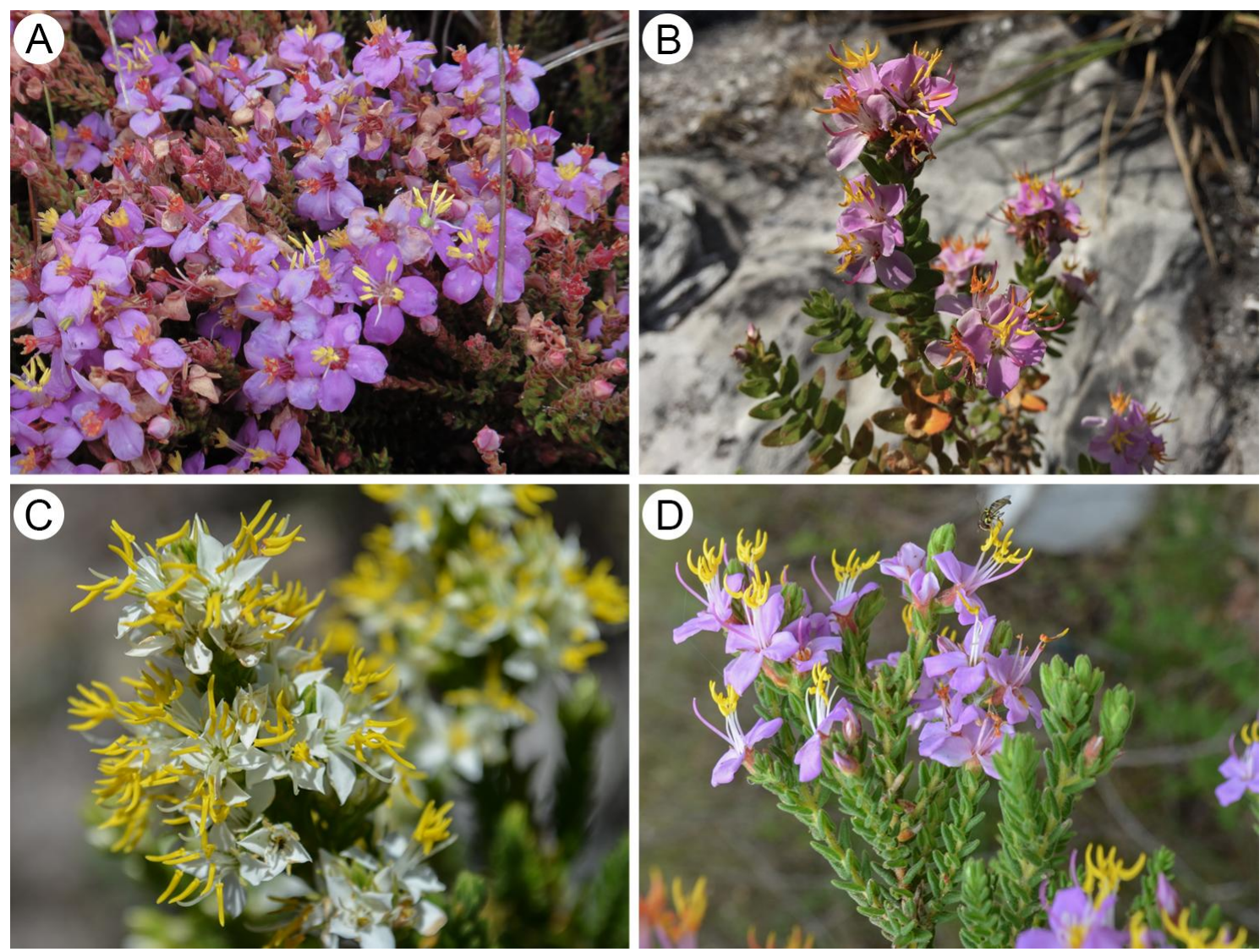

Fig. 4: Marcetia DC. A. M. acerosa Schrank \& Mart. ex DC. B. M. semiriana A.B.Martins. C-D. M. taxifolia (A.St.Hil.) DC. [Fotos: A. R. Romero; B. R. Pacifico; C-D. M.J.R. Rocha].

Material examinado: Minas Gerais, local não indicado. "Cipó, au Rio Preto. Minas Gerais, Brasil", 25.IV.1892, fr., A. Glaziou 19283 (P-05287781-imagem online!, P-05287782-imagem online!, P-05287783-imagem online!). Santana do Riacho, Parque Nacional da Serra do Cipó, Serra das Bandeirinhas, 1400-1500 m, 27.VII.1991, fl., A.M. Giulietti et al. CFSC 12475 (SPF-73856-imagem online!); idem, km 6 da Rodovia MG10, Santana do Riacho para Conceição do Mato Dentro, Serra do Cipó, 19¹8'17"S, 4336'32"W, 1069 m., 9.II.2007, fl., fr., A.K.A. Santos, 1037 (HUEFS-116879-imagem online!).

Material adicional examinado. Minas Gerais, Diamantina, Parque Estadual do Biribiri, Jatobazeiro, 1808'34"S, 4334'22"W, 1149 m, 4.X.2011, fl., fr., $D$. Marques et al. 320 (HUFU!); idem, estrada Diamantina Conselheiro da Mata, MG 220, km 180, próximo a estrada, 18॰16'36"S, 4343'18"W, $1355 \mathrm{~m}, 23 . I V .2019$, fl., fr., $R$. Romero et al. 9008 (HUFU!).

Embora Marcetia acerosa apresente distribuição restrita à Cadeia do Espinhaço, algumas vezes pode ocorrer em simpatria com $M$. taxifolia, com a qual se assemelha pelos ramos decorticantes e morfologia foliar. No entanto, embora compartilhem tais características, $M$. acerosa é normalmente reconhecida pelo hábito decumbente (vs. ereto em $M$. taxifolia), ausência de apêndices no conectivo ( $v s$. curtamente bilobados), anteras eretas (vs. curvadas), cápsulas excedendo o hipanto ( $v s$. igual ou menor) e presença de dentículos entre as sépalas, os quais estão ausentes em M. taxifolia (Martins 1989, Santos 2020). Na Serra do Cipó, M. acerosa é encontrada em campo rupestre, em solos arenosos, entre 1060-1500 $\mathrm{m}$ de altitude.

5.2. Marcetia semiriana A.B.Martins, Novon 10: 229. 2000.

Fig. 4 B

Ervas ou subarbustos, decumbentes, raramente eretos, $\quad 0,15-0,50 \mathrm{~m}$ alt. Ramos subcilíndricos, flexuosos, decorticantes na base, ramos jovens pubérulo-glandulosos. Folhas pecioladas, pecíolos ca. $1 \mathrm{~mm}$ compr.; lâminas 3-12 × 1-6 $\mathrm{mm}$, oval-lanceoladas, base arredondada a 
Flora da Serra do Cipó, Minas Gerais: Marcetieae (Melastomataceae)

subtruncada, ápice obtuso a arredondado, margem inteira, plana, membranáceas, 3 nervuras, ambas as faces pubérulo-glandulosas. Flores solitárias, axilares; bractéolas 4-5 × 1-2 mm; pedicelos ca. $1 \mathrm{~mm}$ compr.; hipantos 2-2,5 × 1,5-2,4 mm compr., estreitamente campanulados, pubérulo-glandulosos; sépalas $2-3 \times$ ca. $1 \mathrm{~mm}$, linear-lanceoladas; pétalas $5-7 \times 3-5 \mathrm{~mm}$, obovais a elípticas, púrpuras, róseas ou lilases; estames isomórficos, filetes ca. $3 \mathrm{~mm}$ compr., brancos, pedoconectivos inconspícuos, levemente espessos na base das tecas, inapendiculados; anteras 2-4 mm compr., oblongas, eretas, comumente amarelas ou alaranjadas; ovários 4-loculares, ovoides; estiletes ca. $6 \mathrm{~mm}$ compr. Cápsulas, ca. $3 \mathrm{~mm}$ compr., castanhas, igual ou menor que o hipanto; sementes ca. 0,4 mm compr., cocleadas, testas foveoladas.

Material examinado: Minas Gerais, Conceição do Mato Dentro, "In the vicinity of Alto dos Palácios along road from Chapéu do Sol to Conceição do Mato Dentro in the Serra do Cipó", 14.II.1982, fl., T.F. Daniel et al. 2294 (SPF, UEC-0055457-imagem online!). Congonhas do Norte, Serra do Cipó, vale do Rio Preto, $18^{\circ} 50^{\prime} 58^{\prime \prime} \mathrm{S}, 43^{\circ} 44^{\prime} 55^{\prime \prime} \mathrm{W}, 1285 \mathrm{~m}$, 2.IX.2016, fl., R. Pacifico et al. 208 (CAS, HUEM-32932imagem online!, SPF). Jaboticatubas, Serra do Cipó, ao longo da rodovia Lagoa Santa-Conceição do Mato Dentro-

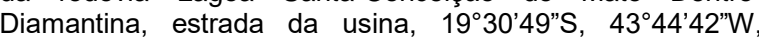
18.X.1973, fl., A.B. Joly 4553A (UEC-10637-imagem online!). Santana do Riacho, Serra do Cipó, km 132, 24.IV.1950, fl., fr., A.P. Duarte 2647 (US-01900814-imagem online!); idem, ao longo da rodovia Belo Horizonte-Conceição do Mato Dentro, 22.II.1986, fl., N.S.C. Chukr et al. CFSC 9624 (SPF00041940-imagem online!); idem, Serra do Cipó. Rodovia Belo Horizonte-Conceição do Mato Dentro, km 106, 19¹0'08"S, 4342'52"W, 16.XI.1984, fl., J.R. Pirani \& D.Zappi CFCR 6087 (HUEFS-132026-imagem online!, SPF00034937-imagem online!); idem, rodovia Belo Horizonte-Alto do Palácio, caminho para a Cachoeira, 16.I.1988, fl., N.L. Menezes \& P. Morales CFSC 10852 (HUEFS-132027imagem online!, SPF-00060125-imagem online!, UEC099200-imagem online!); idem, caminho para cachoeira da Capivara, 31.III.1988, fl., D.C. Zappi CFSC 10928 (SPF00060323- imagem online!); idem, trilha para Cachoeira da Capivara, coleta na base de rochas, a sombra, serra do Cipó, 19¹4'21"S, 4333'14"W, $1300 \mathrm{~m}$, 08.II.2007, fl., A.K.A. Santos 1035 (HUEFS-116877-imagem online!); Santana do Riacho, Parque Nacional da Serra do Cipó, Trilha para a

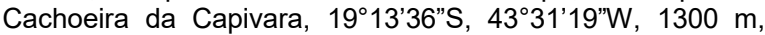
5.VII.2012, fl., G.M. Antar et al. 63 (SPF-00209312-imagem online!); idem, trilha para a Cachoeira da Capivara, acesso pela rodovia MG-010, 19¹0'08"S, 4342'52"W, 5.VII.2012, fl., M.T. Kubo 136 (SPF-00216536-imagem online!). Santana do Pirapama, Serra do Cipó, trilha ao norte de Inhame, passando a cachoeira, $18^{\circ} 55^{\prime} 27^{\prime \prime} \mathrm{S}, 43^{\circ} 47^{\prime} 23^{\prime \prime} \mathrm{W}, 23.1 \mathrm{II} .2011$, fl., D.C. Zappi 3329 (SPF-209652-imagem online!).

Marcetia semiriana é endêmica de Minas Gerais, ocorrendo em campo rupestre, em solos arenosos, das Serra do Cipó e Serra do Cabral (Martins 1989, Candido 2005, Santos 2020). É avaliada na lista das espécies ameaçadas da flora brasileira como em perigo de extinção (EN), devido a ameaças como o fogo e turismo (Martinelli \& Moraes 2013). Marcetia semiriana ocorre em simpatria e é morfologicamente semelhante à $M$. taxifolia (Martins 1989). No entanto, M. semiriana é caracterizada pelo hábito geralmente decumbente (versus ereto em $M$. taxifolia), folhas pecioladas ca. $1 \mathrm{~mm}$ compr. (vs. sésseis ou 0,2-0,8 mm compr.), lâminas foliares com margem plana (vs. revoluta), filetes e estiletes mais curtos (vs. 4-5,5 mm compr., 6-10 mm compr.), anteras menores e eretas (vs. 2,5-3,5 mm compr., curvadas) e pela ausência de apêndices no conectivo (vs. apendiculadas) (Martins 1989, Cândido 2005). Na Serra do Cipó é registrada em afloramentos rochosos e em solos arenosos.

5.3. Marcetia taxifolia (A.St.-Hil.) DC., Prodr. 3: 124. 1828

Fig. 4 C, D

Arbustos ou subarbustos, eretos, 0,15-1 m alt. Ramos cilíndricos a subcilíndricos, decorticantes na base, híspido-glandulosos. Folhas sésseis ou curtamente pecioladas; pecíolos 0,2-0,8 $\mathrm{mm}$ compr.; lâminas 2,5-10 × 0,6-5,5 mm, lineares, lanceoladas ou cordiformes, base cordada a truncada, ápice agudo, margem revoluta, raramente plana, membranáceas ou cartáceas, (1-)3-nervuras, ambas as faces híspido-glandulosas. Flores solitárias, terminais ou axilares, bractéolas $0,3-0,4 \times$ ca. $1 \mathrm{~mm}$ compr.; pedicelos ca. $1 \mathrm{~mm}$ compr.; hipantos 1,5-2,5 $\times$ 2,5-4 mm, campanulados ou cilíndricos, hirsutoglandulosos; sépalas 1-3,5 × 0,4-1 mm, lineares a triangulares; pétalas 3,5-5,5 × 2-4 mm, obovais, ovallanceoladas, lilases, róseas, creme ou brancas; estames dimórficos, filetes 4-5,5 mm compr., brancos ou róseos; pedoconectivos inconspícuos, espessos ventralmente na base das tecas, apêndices ventrais curtamente bilobados; anteras 2,5-3,5 mm compr., lineares a oblongas, curvadas, ápice não rostrado, amarelas; ovários 4-loculares, globosos; estiletes 6-10 $\mathrm{mm}$ compr., brancos ou róseos. Cápsulas, 2,5-3,4 mm compr., globosas, avermelhadas, igual ou menor que o hipanto; sementes $0,3-0,4 \times$ ca. $0,5 \mathrm{~mm}$, cocleadas, testas tuberculadas ou foveoladas.

Material examinado selecionado: Minas Gerais, Conceição do Mato Dentro, "rocky slopes in the vicinity of Alto dos Palácios along road from Chapéu do Sol to Conceição do Mato Dentro in the Serra do Cipó", 1902'14"S, 43²5'30"W, 14.II.1982, fl., T.F. Daniel \& N. Hensold 2274 (UEC-105130imagem online!); idem, serra do Cipó, 1902'14"S, 4325'30"W, 9.V.1952, A. Macedo 3748 (RB!). Congonhas do Norte, Serra do Cipó, próximo à Fazenda Imbaúbas, campo rupestre, ponto $211,18^{\circ} 55^{\prime} 11^{\prime \prime} \mathrm{S}, 43^{\circ} 40^{\prime} 58^{\prime \prime} \mathrm{W}, 1 . \mathrm{IX} .2016$, fl., R. Pacifico et al. 198 (HUEM-32921-imagem online!); idem, serra do Cipó, vale do Rio Preto, campo rupestre, ponto 220, $18^{\circ} 50^{\prime} 59^{\prime \prime S}, 43^{\circ} 44^{\prime} 55^{\prime \prime W}, 2 . I X .2016$, fl., R. Pacifico et al. 209 (HUEM-32933-imagem online!). Jaboticatubas, Serra do Cipó, km 142 - estrada de Conceição, 22.III.1940, fl., H.L. Mello Barreto 10796 (BHCB!); idem, Parque Nacional da

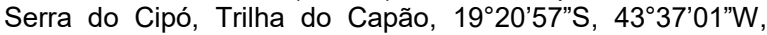
12.V.2012, fl, fr., S.S. Oliveira 39 (BHCB!); idem, Serra do Cipó, km 120, 19³0'49"S, 4344'42"W, 16.I.1999, fl., S.A.P. Godoy et al. 1636 (HUFU!). Morro do Pilar, Serra do Cipó K. 138 estrada rodovia para Pilar, 20.IV.1953, fl., fr., Mendes Magalhães 5901 (BHCB!). PARNA, Serra do Cipó, Alto Palácio, trilha para as Vellozia gigantea, 19¹4'50"S, 
M. J. R. da Rocha et al.

4331'08" W, elevação 1308 m, 15.X.2013, fl., M. Verdi et al. 6558 (RB!); idem, Serra do Cipó. Alto Palácio, trilha para as Vellozia gigantea, 19¹4'50"S, 4331'08'W, elevação 1308 m, 15.X.2013, fl., M. Verdi et al. 6570 (RB!). Santa Luzia, km 134, Serra do Cipó, 15.IV.1935, fl., H.L. Mello Barreto \& A.C. Brade, 1156 (RB!); idem, Serra do Cipó K.115, 6.VIII.1933, fl., H.L. Mello Barreto 6814 (BHCB!); idem, Serra do Cipó, km.110 Vaccaria, 23.VIII.1933, fl., fr., H.L. Mello Barreto 6816 (BHCB!); idem, Serra do Cipó km 127 - Palácio, 23.VIII.1933, fl., H.L. Mello Barreto 6808 (BHCB!); idem, Serra do Cipó km 119, 6.VIII.1936, fl., A.A. Archer \& Mello Barreto 4935 (BHCB!). Santana do Pirapama, Serra do Cipó (Serra da Lapa), distrito de São José da Cachoeira, trilha do João Carrinho, 7561080m, 18.II.2007, fl., V.C. Souza et al. 32682 (BHCB!, ESA97784-imagem online!). Santana do Riacho, Serra do Cipó. km 118, MG 010, Estrada de Santana do Riacho. Platô do Pico do Mirante. 04.VII.1994, fl., F. Vale s.n. (BHCB!); idem, 4.VII.1996, fl., F. Vale s.n. (BHCB!); idem, Serra do Cipó, rodovia Belo Horizonte-Conceição do Mato Dentro, ca de $5 \mathrm{~km}$ após a bifurcação para Morro do Pilar, beira de mata secundária, 05.VII.1996, fl., V.C. Souza et al. 11749 (ESA, BHCB!); idem, Serra do Cipó, km 110, 16.V.2003, fl., fr., L.C.P. Gardoni \& F.H.A. Vale s.n. (BHCB!); idem, Serra do Cipó, km 109, 24.III.2004, fl., F.H.A. Vale et al. s.n. (BHCB!); idem, fazenda Geraldinho, projeto Sempre Viva, 19¹7'26"S, 433' $44^{\circ}$ 'W, 2.III.2012, fl., M.J.R Rocha \& R.C. Ribeiro 358 (BHCB! NY!); idem, Parque Nacional da Serra do Cipó, lado direito da estrada sentido Conceição do Mato Dentro, 19¹5'13"S, 4332'59"W, 14.III.2012, fl., M.J.R. Rocha et al. 365 (BHCB! NY!); idem, Serra do Cipó, 19¹7'53"S, 4335'28"W, 30.V.2012, fl. B.G. Ferreira 1 (BHCB!); idem, PARNA Serra do Cipó, trilha do Capão, $19^{\circ} 21^{\prime} 04^{\prime \prime S}, 4^{\circ} 37^{\prime} 05 \mathrm{~W}, 3$. VII.2014, fl., V.C. Souza et al. 38083 (RB!); idem, Serra do Cipó, rodovia MG-010, próximo ao córrego Três Pontinhas na estrada velha [19268083; -43602850], 4.IV.2017, fl., V.C. Souza 40631 (RB!); idem, Parque Nacional da Serra do Cipó, Cardeal Mota, 19¹5'46"S, 4331'27"W, 9.VIII.2018, fl., J.A.M. Paiva \& S.H.A. Silva 1846 (BHCB!).

Marcetia taxifolia é a única espécie no gênero que possui distribuição ampla no Brasil, uma vez que as demais espécies estão restritas à região leste do
Brasil (Martins 1989), particularmente na Chapada Diamantina (Santos 2009). Além do Brasil, há registros para Venezuela, Colômbia e Guiana (Martins 1989). $\mathrm{Na}$ Serra do Cipó ocorre em campo rupestre e cerrado, em diferentes tipos de ambientes, tais como fendas e depressões na rocha, próximo à drenagem de rios, e em altitudes variáveis. Além disso, observamos populações com variação na morfologia floral, notadamente quanto à coloração das pétalas.

\section{Siphanthera Pohl ex DC., Prodr. 3: 121. 1828.}

Ervas ou subarbustos, eretos. Ramos cilíndricos ou obscuramente quadrangulares, glandulosos. Folhas sésseis ou curto pecioladas, pubescentes ou glabras. Flores 4-meras, em panículas, axilares e/ou terminais, brácteas semelhantes às folhas; hipantos inconspicuamente 8estriados; sépalas creme, esverdeadas ou vináceas; pétalas brancas, róseas ou purpúreas; estames 4 , isomórficos, ou 8, subisomórficos; filetes glabros, pedoconectivos curtos, dorsalmente espessos, apêndices ventrais bilobados, anteras ovoides ou oblongas, eretas, ápice rostrado ou truncado, amarelas; ovários súperos, 2-loculares, glabros; estiletes glabros; estigmas punctiformes ou truncados. Frutos cápsulas; sementes elipsoides a lacrimiformes, testas foveoladas.

Siphanthera é um gênero neotropical com 15 espécies distribuídas no Brasil, Bolívia, Colômbia, Guiana, Suriname, Peru e Venezuela (Almeda \& Robinson 2011). No Brasil, é representado por 12 espécies (Goldenberg et al. 2020), ocorrendo, principalmente, em campo úmido com solo arenoso ou pedregoso. Em Minas Gerais ocorrem sete espécies, das quais três são endêmicas do estado (Romero 1997, Goldenberg et al. 2020).

1. Estames 8; anteras oblongas

6.2 S. paludosa

1 '. Estames 4; anteras ovoides.

2. Anteras com ápice rostrado, poro estreito

6.1 S. arenaria

2 '. Anteras com ápice truncado, poro amplo.....

6.1 Siphanthera arenaria (DC.) Cogn. in Mart., FI. Bras. 14(3): 193. 1883.

Fig. $3 \mathrm{C}$

Ervas, $0,1-0,3 \mathrm{~m}$ alt. Ramos obscuramente quadrangulares, densamente glandulosos, de coloração avermelhada. Folhas sésseis; lâminas 3,5-8 $\times 2-6,5 \mathrm{~mm}$, oval-oblongas, base arredondada, às vezes cordada, ápice agudo, margem inteira, membranáceas, 3 nervuras raramente 5 , ambas as faces glandulosas. Panículas, axilares ou terminais; bractéolas ca. $2 \times 0,5 \mathrm{~mm}$; pedicelos ca. $2 \mathrm{~mm}$ compr.; hipantos ca. $1,5 \times 2 \mathrm{~mm}$, campanulados, avermelhados, densamente glandulosos, tricomas setoso-glandulosos; sépalas ca. 1,6 × $1 \mathrm{~mm}$, triangulares, frequentemente avermelhadas, raramente verdes; pétalas ca. 2,5 × 2,5 mm, obovais, levemente unguiculadas, róseas; estames 4; antessépalos com filetes ca. $1,5 \mathrm{~mm}$ compr.; pedoconectivos ca. $0,1 \mathrm{~mm}$ compr., anteras ca. $1 \mathrm{~mm}$ compr., ovoides, ápice curtamente rostrado, rostros ca. 0,3 mm compr., poro estreito, terminal; estiletes ca. 
Flora da Serra do Cipó, Minas Gerais: Marcetieae (Melastomataceae)

$3 \mathrm{~mm}$ compr.; estigmas punctiformes. Cápsulas, ca. 2 $\times 2 \mathrm{~mm}$, globosas; sementes ca. 0,3 × 0,2 mm, elipsoides.

Material examinado: Conceição do Mato Dentro, Serra do Cipó, km 141, estrada de Conceição, W.A. Archer \& H.L. Mello Barreto 5025, 6.VIII.1936, fl. (BHCB!). Congonhas do Norte, Serra do Cipó, $18^{\circ} 52^{\prime} S, 43^{\circ} 46^{\prime} \mathrm{W}$, 22.IV.1982, fl., M.C.E. Amaral CFSC 8417 (SPF). Jaboticatubas, Serra do Cipó, km 126 na estrada para Conceição do Mato Dentro, $19^{\circ} 10^{\prime} \mathrm{S}, 43^{\circ} 30^{\prime} \mathrm{W}$, 1.VI.1998, fl., F. Almeda et al. 7773 (HUFU!, UEC!); idem; Parque Nacional da Serra do Cipó, 2.VI.1998, fl., F. Almeda et al. 7786 (HUFU!); idem, Serra do Cipó, Fazenda Cachoeira da Capivara, 5.VII.2001, fl., V.C. Souza et al. 25153 (HUFU!); idem, Serra do Cipó, km 132 ao longo da rodovia Lagoa SantaConceição do Mato Dentro-Diamantina, 7.VI.1970, A.B. Joly et al. CFSC 242 (SP); idem, Serra do Cipó, 21.IV.2012, fl., S. Alcântara \& N.M. Castro 20 (HUFU!). Santa Luzia, Serra do Cipó, km 138, 1946'11"S, 4351'05'W, 15.IV.1935, fl., H.L. Mello \& A.C. Brade 1162 (BHCB!). Santana do Pirapama, Serra do Cipó, Capela de São José. Estrada da Captação da Fazenda Toucan Cipó, 1900'12"S, 4345'21"W, 10.III.2010, fl., D.C. Zappi 2781 (SPF); idem, Serra do Cipó, trilha da Senhorinha, topo da serra, $18^{\circ} 55^{\prime} 32$ "S, 4345'03"W, 27.VII.2009, fl., D.C. Zappi 2265 (SPF); idem, Serra do Cipó, Faz. Inhame (Serra Mineira), $18^{\circ} 55^{\prime} \mathrm{S}$, 435'W, 22.III.1982, fl., J.R. Pirani CFSC 8093 (SP, SPF). Santana do Riacho, Serra do Cipó, estrada Lagoa SantaConceição do Mato Dentro, 7.VI.1989, fl., A.A.A. Barbosa 411 (HUFU); idem, Serra do Cipó, Retiro do Alto do Palácio, $25 \mathrm{~km}$ NE de Cardeal Mota caminho a Conceição do Mato Dentro, 16.V.1990, fl., M.M. Arbo et al. 4253 (HUFU!); idem, Serra do Cipó, campo próximo à sede do IBAMA do Alto do Palácio, 24.III.1991, fl., J.R. Pirani et al. 11912 (HUFU!); idem, Serra do Cipó, estrada para Conceição do Mato Dentro, Alto do Palácio, $19^{\circ} 16^{\prime} 19^{\prime \prime}$, 4332'20'W, 29.VI.2015, fl., R. Romero et al. 8601 (HUFU!); idem, Serra do Cipó, APA Morro da Pedreira, estrada de terra que parte do km 135 da rodovia MG-010, 1909'44"S, 4330'44'W, fl., 28.IV.2015, fl., R. Pacifico \& A. Carmo 143 (HUEM-000015820-imagem on line!, UEC-142376-imagem on line!), trilha Vellozia gigante, $19^{\circ} 10^{\prime} 08^{\prime \prime} S, 43^{\circ} 42^{\prime} 52^{\prime \prime} \mathrm{W}$, 20.IV.2013, fl., A.M. Vale 275 (BHCB!); idem, Parque Nacional da Serra do Cipó. Alto Palácio, atrás da casa do Ibama, 19¹0'08"S, 4342'52'W, 18.VI.2012, fl., M.J.R. Rocha \& R.C. Ribeiro 710 (BHCB!, NY); idem, Serra do Cipó, km 125 da rodovia Belo Horizonte-Conceição do Mato Dentro, elevação em frente à estátua do Velho Juca, 26.III.1991, fl., J.R. Pirani et al. 120 (HUFU!).

Siphanthera arenaria é endêmica de Minas Gerais (Romero 1997, Almeda \& Robinson 2011, Goldenberg et al. 2020), ocorrendo exclusivamente em campo limpo e campo úmido da Cadeia do Espinhaço, em solo arenoso. Siphanthera arenaria é reconhecida por suas flores 4-meras com pétalas róseas, levemente unguiculadas, e indumento avermelhado recobrindo ramos, lâminas foliares, hipantos e sépalas.

6.2. Siphanthera paludosa (DC.) Cogn. in Mart., Fl. bras. 14(3): 199. 1883.

Fig. $3 \mathrm{D}$

Ervas, 0,3-0,4 m alt. Ramos cilíndricos, densamente adpresso-seríceos e entremeados por tricomas glandulosos, de coloração creme ou acastanhada. Folhas sésseis; lâminas 8-18 × 6-12 $\mathrm{mm}$, ovais ou oval-oblongas, base arredondada, ápice agudo, margem inteira, membranáceas, 5 nervuras, face adaxial moderada a densamente vilosa, face abaxial densamente vilosa, principalmente nas nervuras, coloração creme ou acastanhada. Panículas terminais, multifloras; bractéolas ca. 1,5 × 0,5 mm; pedicelos ca. $2 \mathrm{~mm}$ compr.; hipantos ca. $2 \times 1,8 \mathrm{~mm}$, campanulados, moderadamente glandulosos; sépalas ca. $2,5 \times 1 \mathrm{~mm}$, triangulares; pétalas $4-5 \times$ ca. $4 \mathrm{~mm}$, obovais, levemente unguiculadas, roxas; estames 8 , subisomórficos; filetes 1.5-2.5 mm compr.; pedoconectivos 0,1-0,3 $\mathrm{mm}$ compr.; anteras 1-2 mm compr., oblongas, ápice rostrado; rostros $0,5-1 \mathrm{~mm}$ compr., poro estreito, terminal; estiletes ca. $5 \mathrm{~mm}$ compr.; estigmas punctiformes. Cápsulas, ca. $2 \times 2$ $\mathrm{mm}$, globosas; sementes ca. 0,3 ×0,2 mm, elipsoides.

Material examinado: Minas Gerais, Conceição do Mato Dentro, Serra do Cipó, 1902'14"S, 43²5'30"W, 13.II.2002, bot., N. Roque 143 (SPF); idem, Serra do Cipó, km 142, estrada de Conceição, 16.IV.1935, fl., H.L. Mello Barreto \& A.C. Brade 1160 (BHCB!). Jaboticatubas, Serra do Cipó, Retiro do Alto do Palácio, $25 \mathrm{~km}$ NE de Cardeal Mota caminho a Conceição do Mato Dentro, 16.V.1990, fl., M.M. Arbo et al. 4278 (HUFU!); idem, Parque Nacional da Serra do Cipó, 19¹0'S, 4330'W, 6.II.1998, bot., F. Almeda et al. 7787 (HUFU!, UEC); idem, Serra do Cipó, km 132 ao longo da rodovia Lagoa Santa-Conceição do Mato Dentro-Diamantina, $19^{\circ} 30^{\prime} 49^{\prime \prime S}$, 434ㄴ'42"W, 6.III.1972, fl., A.B. Joly et al. CFSC 1377 (SP); idem, Serra do Cipó, km 132 ao longo da rodovia Lagoa Santa-Conceição do Mato DentroDiamantina, $19^{\circ} 30^{\prime} 49^{\prime} \mathrm{S}, 43^{\circ} 44^{\prime} 42^{\prime \prime W}, 7 . V I .1970$, fl., A.B. Joly et al. CFSC 242 (SP). Santa Luzia, Serra do Cipó, estrada de Conceição, km 138, 1946'11"S, 4351'05"W, 15.IV.1935, fl., H.L. Mello Barreto \& A.C. Brade 1170 (BHCB!). Santana de Pirapama, Serra do Cipó, Capela de São José, trilha da Senhorinha, caminho a Congonhas do Norte, 1857'31"S, 4344'18"W, 25.XI.2009, fl., D.C. Zappi 2537 (SPF); idem, Serra do Cipó, Fazenda Inhame (Serra Mineira), $18^{\circ} 55^{\prime} \mathrm{S}, 43^{\circ} 54^{\prime} \mathrm{W}$, 23.III.1982, fl., J.R. Pirani et al. CFSC 8186 (HUFU!, SP, SPF). Santana do Riacho, entroncamento para Morro do Pilar, campo graminoso úmido, margem da estrada, $19^{\circ} 10^{\prime} 08^{\prime \prime S}, 43^{\circ} 42^{\prime} 52^{\prime \prime W}$, 14.XI.2013, fl., M.J.R. Rocha \& R.P. Pena 896 (BHCB!); idem, Serra do Cipó, RPPNs Brumas do Espinhaço e Ermos dos Gerais, 19॰10'08"S, 4342'52"W, 11.IV.2014, fl., B.M. Carvalho s.n. (BHCB!); idem, RPPN Brumas do Espinhaço e Ermo dos

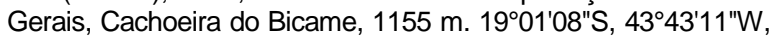
15.V.2012, fl., I.R. Andrade et al. 342 (BHZB!).

Siphanthera paludosa é endêmica de Minas Gerais, ocorrendo exclusivamente na Cadeia do Espinhaço, em campo limpo e campo úmido, em solo arenoso (Romero 1997, Almeda \& Robinson 2011). Siphanthera paludosa é reconhecida pelas flores 4meras com oito estames subisomórficos, anteras rostradas e indumento de coloração creme ou acastanhada recobrindo ramos e ambas as faces das lâminas foliares.

6.3. Siphanthera wurdackii Almeda \& O.R.Rob., Syst. Bot. Monogr. 93: 88. 2011.

Ervas, $\quad 0,04-0,12 \mathrm{~m}$ alt. Ramos quadrangulares ou subquadrangulares, esparsa a 
moderadamente glandulosos, coloração creme a acastanhada. Folhas sésseis ou subsésseis; pecíolos até $2,5 \mathrm{~mm}$ compr.; lâminas $2-5 \times 2-4 \mathrm{~mm}$, ovais, subcordadas a elíptico-ovais, base arredondada a cordada, ápice agudo, margem inteira a levemente serreada, ciliada, cartáceas, 3-5 nervuras, face adaxial moderadamente a densamente setosa, face abaxial setosa e entremeada por tricomas glandulosos, coloração creme a acastanhada. Panículas terminais, multifloras; bractéolas ca. $2 \times$ 0,5-1 mm; pedicelos 3-4 mm compr.; hipantos 1-1,2 $\times$ ca. $1,5 \mathrm{~mm}$, globosos, moderadamente glandulosos; sépalas 1,5-2 × 0,7-1 mm, triangulares; pétalas ca. 3 $\times 3 \mathrm{~mm}$, ovais a suborbiculares, róseas; estames 4 , isomórficos; filetes ca. $1 \mathrm{~mm}$ compr.; pedoconectivos ca. 0,2 mm compr.; anteras ca. $1 \mathrm{~mm}$ compr., ovoides, ápice truncado, não rostrado, poro amplo, inclinado ventralmente; estiletes ca. $2 \mathrm{~mm}$ compr.; estigmas capitados. Cápsulas, ca. $2 \times 2 \mathrm{~mm}$, globosas; sementes ca. $0.3 \times 1 \mathrm{~mm}$, elipsoides, testas reticuladas.

Material examinado: Minas Gerais, Congonhas da Serra, 1892, fl., fr., A. Glaziou 19280 (K!, P!).

Siphanthera wurdackii é endêmica de Minas Gerais, ocorrendo nas proximidades de Grão-Mogol e Congonhas da Serra, em campo rupestre, em solo arenoso (Almeda \& Robinson 2011). Siphanthera wurdackii é reconhecida pelas flores 4-meras, com quatro estames, anteras ovoides, ápice truncado e com um poro amplo inclinado ventralmente.

\section{Agradecimentos}

Agradecemos aos curadores dos herbários $\mathrm{BHCB}, \mathrm{HUFU}$ e RB por disponibilizar materiais para estudo e aos demais herbários citados por disponibilizar acesso às imagens virtuais dos espécimes estudados; à Daniela Cristina Zappi e ao Ricardo Pacifico por ceder fotos de campo, e à Ariadne Lopes pela confecção das pranchas. MJRR e $\mathrm{RR}$ agradecem ao ICMBio e à equipe do PARNA da Serra do Cipó pela licença de coleta concedida ( $\mathrm{n}^{\circ}$ 33299-4). MJRR também é grata à Coordenação de Aperfeiçoamento de Nível Superior (CAPES), à Fundação de Amparo à Pesquisa do estado de Minas Gerais (FAPEMIG) e ao Conselho Nacional de Desenvolvimento Científico e Tecnológico (CNPq) pelas bolsas concedidas durante a realização do Doutorado, que viabilizaram as suas coletas. RR agradece à Universidade Federal de Uberlândia pelo apoio financeiro para expedição de campo à Serra do Cipó e à FAPEMIG (processo APQ01911-16) por apoiar pesquisas com a família Melastomataceae no estado de Minas Gerais. DNS é grato ao CNPq pela sua bolsa de Iniciação Científica (PIBIC/CNPq-JBRJ, 126491/2018-6) que financiou seus estudos com Fritzschia e também à CAPES pela sua bolsa de Mestrado (processo 88882.447047/2019-01 - Código de Financiamento 001).

\section{Referências}

ALMEDA, F. \& ROBINSON,O.R. 2011. Systematics and phylogeny of Siphanthera (Melastomataceae). Syst. Bot. Monogr. 93: 1-101.

CAETANO, A.P.S., BASSO-ALVES, J.P., CORTEZ, P.A., BRITO, V.L.G., MICHELANGELI, F.A., REGINATO, M., GOLDENBERG, R., CARMELLOGUERREIRO, S.M. \& TEIXEIRA, S.P. 2018. Evolution of the outer ovule integument and its systematic significance in Melastomataceae. Bot. J. Linn. Soc. 186(2): 224-246. https://doi.org/ 10.1093/botlinnean/box093.

CANDIDO, C.P. 2005. A família Melastomataceae na Serra do Cabral-MG: tribos Melastomeae, Merianieae e Miconieae. Dissertação de Mestrado, Universidade Estadual de Campinas. Campinas.

CHAMISSO, A. 1834. De plantis in expeditione speculatoria romanzoffiana et in herbariis regiis berolinensibus observatis. Melastomaceae americanae. Linnaea 9(3): 368-402.

FREIRE-FIERRO, A. 2002. Monograph of Aciotis (Melastomataceae). Syst. Bot. Monogr. 62: 1-99.

GIULIETTI, A.M, MENEZES, N.L., PIRANI, J.R., MEGURO, M. \& WANDERLEY, M.G.L. 1987. Flora da Serra do Cipó, Minas Gerais: caracterização e lista das espécies. Bol. Bot. Univ. São Paulo 9: 1151. https://doi.org/10.11606/issn.2316-9052. v9i0p1-151.

GOLDENBERG, R., MICHELANGELI, F.A. \& ALMEDA, F. 2020. Siphanthera in Flora do Brasil 2020 em construção. <http://reflora.jbrj.gov.br/ reflora/floradobrasil/FB9870>. Acesso em: 07 Abr. 2020.

GUIMARÃES, P.J.F., OLIVEIRA DA SILVA, M.F. \& ROCHA, M.J.R. 2017. Nomenclator botanicus for Acisanthera (Melastomataceae: Marcetia alliance). Brittonia 69(2): 231-240. http://doi.org/10.1007/ s12228-017-9463-7.

MARTINELLI, G. \& MORAES, M.A. 2013. Livro vermelho da flora do Brasil. Ed. 1. Andrea Jakobsson / Instituto de Pesquisas Jardim Botânico do Rio de Janeiro. Rio de Janeiro.

MARTINS, A.B. 1989. Revisão taxonômica do gênero Marcetia DC. (Melastomataceae). Tese de Doutorado, Universidade Estadual de Campinas. Campinas.

MARTINS, A.B. 2000. Three new Brazilian species in the genus Marcetia (Melastomataceae, Melastomeae). Novon 10(3): 224-229. http://doi.org/10.2307/3393104. 
Flora da Serra do Cipó, Minas Gerais: Marcetieae (Melastomataceae)

MICHELANGELI, F.A., GUIMARÃES, P.J.F., PENNEYS, D.S., ALMEDA, F. \& KRIEBEL, R. 2013. Phylogenetic relationships and distribution of New World Melastomeae (Melastomataceae). Bot. J. Linn. Soc. 171(1): 38-60. https://doi.org/10.1111/j.1095-8339.2012.01295.x.

PACIFICO, R., ALMEDA, F. \& SILVA, D.N. 2018. Fritzschia rupestris (Melastomataceae: Marcetieae): A new endangered species from the Cadeia do Espinhaço, Minas Gerais, Brazil. Syst. Bot. 43(3): 793-800. http://doi.org/10.1600/ $036364418 \times 697508$.

ROSA, P. \& FREIRE-FIERRO, A. Aciotis in Flora do Brasil 2020 em construção. <http://floradobrasil.jbrj.gov.br/reflora/floradobrasil/ FB9392>. Acesso em: 30 abr. 2020

ROCHA, M.J.R., BATISTA J.A.N., GUIMARÃES, P.J.F. \& MICHELANGELI, F.A. 2016. Phylogenetic relationships in the Marcetia alliance (Melastomae, Melastomataceae) and implications for generic circumscription. Bot. J. Linn. Soc. 181(4): 585-609. https://doi.org/10.1111/j.1095-8339.2012.01295.x.

ROCHA, M.J.R., GUIMARÃES, P.J.F., MICHELANGELI, F.A. \& BATISTA J.A.N. 2018. Taxonomy of Marcetieae: A new neotropical tribe of Melastomataceae. Int. J. Plant Sci. 179(1): 5074. https://doi.org/10.1086/694932.

ROCHA, M.J.R., GUIMARÃES, P.J.F. \& KRIEBEL, R. 2020. Acisanthera in Flora do Brasil 2020 em construção. <http://reflora.jbrj.gov.br/reflora/ floradobrasil/FB9395>. Acesso em: 07 Abr. 2020.

ROMERO, R. 1997. O gênero Siphanthera Pohl ex DC. (Melastomataceae) no estado de Minas Gerais. Rev. bras. Bot. 20(2): 175-183. http://doi.org/10.1590/S0100-84041997000200008.

ROMERO, R. SILVA, D.N., DE-PAULA, O.C. \& ROCHA, M.J.R. 2019. A new endangered species of Fritzschia Cham. (Melastomataceae, Marcetieae) from Espinhaço Range, Minas Gerais, Brazil. Syst. Bot. 44(3): 664-669. http://doi.org/ 10.1600/036364419X15620113920707.
SANTOS, A.K. 2009. Estudos filogenéticos e biossistemáticos no gênero Marcetia DC. (Melastomataceae). Tese de Doutorado, Universidade Estadual de Feira de Santana. Feira de Santana, Bahia.

SANTOS, A.K.A. 2020. Marcetia in Flora do Brasil 2020 em construção. <http://reflora.jbrj.gov.br/ reflora/floradobrasil/FB9646>. Acesso em: 07 Abr. 2020.

SANTOS, A.K.A., MARTINS, A.B. \& SILVA, T.R.S. 2008. Marcetia candolleana (Melastomeae Melastomataceae), a new species from Bahia (Brazil). Kew Bull. 63(3): 315-318. http://doi.org/10.1007/s12225-008-9021-2.

SECO, R.C. 2006. Estudos taxonômicos no gênero Comolia DC. (Melastomataceae - Melastomeae) no Brasil. Dissertação de Mestrado, Universidade Estadual de Campinas. Campinas.

SILVA, D.N. 2018. Revisão taxonômica do gênero Fritzschia Cham. (Marcetieae: Melastomataceae). Monografia de Graduação, Pontifícia Universidade Católica do Rio de Janeiro. Rio de Janeiro.

SILVA, D.N., ROCHA, M.J.R., JESUS, J.C. \& GUIMARÃES, P.J.F. 2019a. First record of Fritzschia Cham. (Melastomataceae, Marcetieae) in the state of Bahia, Brazil. Check List 15(5): 753758. https://doi.org/10.15560/15.5.753.

SILVA, D.N., ROCHA, M.J.R. \& GUIMARÃES, P.J.F. 2019b. Fritzschia atropurpurea (Melastomataceae, Marcetieae): A new species from the Serra do Cipó, Minas Gerais, Brazil. Syst. Bot. 44(4): 844850. http://doi.org/10.1600/ 036364419X15710776 741512.

SILVA, D.N., ROCHA, M.J.R. \& GUIMARÃES, P.J.F. 2020. Fritzschia in Flora do Brasil 2020 em construção. <http://reflora.jbrj.gov.br/reflora/ floradobrasil/FB9467>. Acesso em: 05 Abr. 2020.

SILVA-GONÇALVES, K.C. 2020. Macairea in Flora do Brasil 2020 em construção. <http://floradobrasil. jbrj.gov.br/reflora/floradobrasil/FB19632>. Acesso em: 09 Abr. 2020. 